\title{
Isolated Nocardiosis, an Unrecognized Primary Immunodeficiency?
}

\begin{abstract}
Rubén Martínez-Barricarte ${ }^{1,2 *}$
${ }^{1}$ Division of Genetic Medicine, Department of Medicine, Vanderbilt Genetics Institute, Vanderbilt University Medical Center, Nashville, TN, United States, ${ }^{2}$ Department of Pathology, Microbiology, and Immunology, Vanderbilt Center for Immunobiology, Vanderbilt Institute for Infection, Immunology, and Inflammation, Vanderbilt University Medical Center, Nashville, TN, United States
\end{abstract}

Nocardiosis is an infectious disease caused by the gram-positive bacterium Nocardia spp. Although it is commonly accepted that exposure to Nocardia is almost universal, only a small fraction of exposed individuals develop the disease, while the vast majority remain healthy. Nocardiosis has been described as an "opportunistic" disease of immunocompromised patients, suggesting that exposure to the pathogen is necessary, but a host predisposition is also required. Interestingly, increasing numbers of nocardiosis cases in individuals without any detected risk factors, i.e., without overt immunodeficiency, are being reported. Furthermore, a growing body of evidence have shown that selective susceptibility to a specific pathogen can be caused by a primary immunodeficiency (PID). This raises the question of whether an undiagnosed PID may cause nocardiosis affecting otherwise healthy individuals. This review summarizes the specific clinical and microbiological characteristics of patients with isolated nocardiosis published during the past 30 years. Furthermore, it gives an overview of the known human immune mechanisms to fend off Nocardia spp. obtained from the study of PIDs and patients under immunomodulatory therapies.

Keywords: Nocardia, nocardiosis, infection, primary immunodeficiencies, immune response, isolated nocardiosis, PID

\section{INTRODUCTION}

In 1888, while investigating a disease in cattle called "francine du boeuf," the veterinarian Edmond Nocard identified a gram-positive, acid-fast agent as causative of this disease (1). A year after, Trevisan named this genus Nocardia in honor of Nocard (2). Shortly thereafter, Eppinger isolated from the brain abscess of a 52-year-old patient, an organism that produced star-shaped colonies when grown in agar. Although he called it Cladothrix asteroides, it was later found to be Nocardia asteroides. This finding made Nocardia be the first human pathogenic aerobic actinomycete described in the literature $(3,4)$. Since then and until the advent of antibiotics, over 30 cases of nocardiosis were described published, all but three with fatal outcome or very severe sequelae (5). After the generalization of antibiotic therapy, recovery rates improved to $54 \%$, and an increased number of patients were every year (6). At this point, reports started to associate nocardiosis with underlying conditions. The first of such reports was published in 1954 in a patient with nocardiosis during Hodgkin's lymphoma (7). Many reports followed showing cases of nocardiosis in patients with alveolar proteinosis (8), prolonged steroid usage $(9,10)$, 
Cushing's syndrome (11), patients under immunosuppressive drugs after transplantation (12) or neoplastic disorders (6) amongst other pathologies (Table 1). Besides, reports started to be published describing severe nocardiosis in patients with primary immunodeficiencies (PID) such as hypogammaglobulinemia $(13,14)$, or chronic granulomatous disease (CGD) (15-17) (Table 2). At this point, nocardiosis was proposed to be an opportunistic infection (19-21). That notion was accepted in the mid-80s after a growing number of nocardiosis cases were described in patients with AIDS (22-24). Interestingly, epidemiological studies in the United States of America indicated that not all patients with nocardiosis suffer from underlying disease $(25,26)$. As a matter of fact, according to the Center for Disease Control (CDC), one-third of nocardiosis patients have no known underlying condition. Furthermore, a growing body of evidence shows that severe infectious diseases in otherwise healthy individuals can arise from single-gene inborn errors of immunity $(27,28)$. Some examples of this are mendelian susceptibility to mycobacterial disease (MSMD) (28), human papillomavirus-associated epidermodysplasia verruciformis (29), invasive pneumococcal disease (30), invasive dermatophytic disease (31), or chronic mucocutaneous candidiasis (32). All these genetic diseases confer a selective susceptibility to a specific pathogen of weak virulence and ubiquitous exposure, muchresembling nocardiosis in patients without identified underlying conditions. In this review, we describe the epidemiological, clinical, and microbiological characteristics of 400 patients with nocardiosis without identified risk factors published during the past 30 years. We have also reviewed what we have learnt from patients with PIDs and patients with different comorbidities about the critical players of human immunity to Nocardia spp.

\section{EPIDEMIOLOGY}

The description of patients with isolated nocardiosis after the HIV outbreak has been increasing steadily since the mid$80 \mathrm{~s}$, as evidenced by the number of case reports published in the literature over the last 30 years (Figure 1A). All the reported cases were sporadic, and no underlying condition was identified in any of them. Moreover, they did not come from consanguineous marriages, or the consanguinity was not indicated except in one patient (298). None of these patients were immunologically or genetically studied in search of a PID or other genetic defects. Patients with isolated nocardiosis have been found in 44 different countries spreading through 6 continents (all except Antarctica) with the USA, India, and Mexico having the most cases reported (Figure 1B). Contrary to other infectious diseases, nocardiosis is not a geographically confined disease, consistent with the fact that Nocardia spp. can be found throughout the world. We have observed that the number of males with isolated nocardiosis almost doubles that of female cases, similar to observations in immunocompromised individuals (25) (Figure 1C). Given that Nocardia spp. grow in soil; these gender biases may be due to a difference in exposure caused by the distinct lifestyle and profession of man vs.
TABLE 1 | Some risk factors for nocardiosis.

\section{Diseases}

AIDS

Solid-organ transplant

Chronic obstructive pulmonary disease

Chronic kidney disease

Cushing's syndrome

Pulmonary fibrosis

Diabetes mellitus

Systemic Lupus erythematosus

Hematopoietic stem cell transplantation

Drug abuse

Malignancies

End-stage renal disease

Membranoproliferative glomerulonephritis

Lung sarcoidosis

Pulmonary proteinosis

Alcoholism long history of smoking

women. Besides, the female hormone estradiol has been shown to inhibit the growth of Nocardia brasiliensis in vitro, suggesting that the presence of this hormone might also contribute to the gender difference observed (299). Furthermore, this may be an indication of an undiagnosed X-linked immunodeficiency. We have found a homogeneous distribution among age groups in patients with isolated nocardiosis with a slight increase in the numbers of patients in the decades of 31-40 and 5160 years of age (Figure 1D). This age distribution suggests that disease occurs when exposure to the pathogen happens thought life without any specific age group been overrepresented or more susceptible. Transmission of Nocardia spp. do not occur from person to person, and outbreaks are rare. Since the 80 s, a handful of outbreaks have been reported in the UK, France, Japan, Germany, and the US. All in groups of patients interned in hospitals and with some level of immunosuppression (300-306). Therefore, this observation indicates that the leading risk factor in developing nocardiosis is the immune status of the host rather than the virulence of the different Nocardia strains.

\section{CLINICAL PRESENTATION}

Nocardiosis can present as a cutaneous disease when the bacterium is inoculated in the skin, usually through a puncture or wound, pulmonary when the bacterium is inhaled and gets to the lungs or disseminated when from these initial foci of infection, it spreads to other organs. In most cases, upon infection, the immune system neutralizes this bacterium, and individuals remain asymptomatic or suffer from a mild selfresolving disease that frequently goes undiagnosed. The classical presentation of pulmonary nocardiosis includes cough, fever, dyspnea, fatigue, and chest pain (307). At the radiological level, it can present as a focal or multifocal disease with 
TABLE 2 | PIDs that can cause nocardiosis.

\begin{tabular}{|c|c|}
\hline Disease & Immunological consequences \\
\hline CGD & $\begin{array}{l}\text { Defects in the NADPH oxidase complex that impairs } \\
\text { the capacity of phagocytes to produce reactive } \\
\text { oxygen species. }\end{array}$ \\
\hline Hypogammaglobulinemia & Reduction in the titers of circulating antibodies. \\
\hline CVID & Deficient levels of $\lg G$, IgA, and $\operatorname{lgM}^{*}$. \\
\hline $\begin{array}{l}\text { Hyper lgE } \\
\text { syndrome }\end{array}$ & $\begin{array}{l}\text { Elevated serum lgE level, chronic dermatitis, intense } \\
\text { pruritus, and severe recurrent infection. }\end{array}$ \\
\hline $\begin{array}{l}\text { Idiopathic CD4 }{ }^{+} \\
\text {T-lymphocytopenia }\end{array}$ & Low levels of CD4+ $\mathrm{T}$ cells. \\
\hline SCID & Lack of B and T cells. \\
\hline MSMD & IL-12 and IL-23 abolishment ${ }^{\star \star}$. \\
\hline $\begin{array}{l}\text { Anti-GM-CSF } \\
\text { autoantibodies }\end{array}$ & Blockade of GM-CSF. \\
\hline \multicolumn{2}{|c|}{$\begin{array}{l}{ }^{*} \mathrm{CVID} \text { is a heterogeneous group of diseases that can present with multiple different } \\
\text { immunological abnormalities. The immunological consequences shown here are the ones } \\
\text { observed in the patient reported in Singh et al. (18). } \\
{ }^{\star *} \text { The genetic causes of MSMD can impair multiple branches of IFN- } \gamma \text {-mediated immunity. } \\
\text { The genetic etiologies of MSMD that sometimes curse with nocardiosis impair IL-12 and } \\
\text { IL-23 signaling. }\end{array}$} \\
\hline
\end{tabular}

infiltrates (nodular or consolidated) and pleural effusion (308). In the case of cutaneous or subcutaneous nocardiosis, the lesions usually show expanding nodules, cellulitis, and ulcerative draining lesions. A fraction of cutaneous nocardiosis develops as mycetoma. These lesions are chronic, slow-progressing, and painless, usually in the lower limbs that present with tumefaction, destructive granuloma, deformity, subcutaneous nodules, and discharging sinuses that exude pus (309). In a priori, immunocompetent individuals, a sizable number of patients have keratitis caused by Nocardia spp. Keratitis usually happens after cornea injury in contact lenses wearers, causing the inoculation of the pathogen. It presents as an inflammatory eye condition, pain, photophobia, and visual impairment. If untreated or misdiagnosed, it might lead to endophthalmitis (309). From the primary foci of infection, the disease can disseminate hematogenously potentially to any organ in the body, and after dissemination occurs, mortality and morbidity increase dramatically. Nocardia spp. have a particular tropism for the CNS. When dissemination happens there, the disease tends to present as headache, seizures, mental status change, confusion, ataxia, or focal neurological deficit may appear. A brain abscess is usually visible by computed tomography (CT) or magnetic resonance imaging (MRI) scans (310). It has been proposed that pulmonary nocardiosis is a disease of immunocompromised individuals, while the cutaneous disease is observed in immunocompetent individuals (308). However, indepth immunological and genetic studies of patients with a priori, no additional risk factors have not been performed, preventing us from concluding if these patients referred to in the literature as immunocompetent have an undiagnosed immunodeficiency. We observed that the majority of cases of isolated nocardiosis showed cutaneous disease (Figure 2A). However, we also found a sizeable number of patients with pulmonary nocardiosis without underlying conditions. In both cases of isolated nocardiosis, cutaneous, and pulmonary, dissemination from the primary foci of infection is about $45 \%$ (Figure 2A). Patients with keratitis caused by Nocardia spp., except in one case, do not present with disseminated disease. Besides, $15 \%$ of patients reported presented with a disseminated disease without identification of the primary location of the infection (Figure 2A). When dissemination happened, the organs to which the disease disseminated was dependent on the original site of infection. In more than half of the patients with dissemination from cutaneous infection, the organs affected were the lymph nodes closest to the location of infections. In $12 \%$ of the cases, the dissemination occurred to multiple organs, and in $11 \%$, cutaneous nocardiosis gave rise to bone involvement, often osteomyelitis (Figure 2B). Other organs such as CNS, muscle, lung, salivary gland, or ovaries were involved in some patients. When dissemination occurred from primary pulmonary infection, $62 \%$ of the patients developed CNS nocardiosis, 15\% suffered from multiorgan dissemination, and in $12 \%$, the disease disseminated to the closest lymph nodes (Figure 2C). Other organs were also described to be affected in some patients, such as bone or mediastine.

\section{MICROBIOLOGY}

Nocardia is a genus of aerobic gram-positive bacteria of the order Actinomycetales. It is characterized by weak acid-fast stain, catalase-positive, presence of mycolic acid in its cell wall, and rod-shaped that grows in branches, sometimes confusing itself with fungi. It can be found in soil and areas rich in organic material. Nocardia has also been reported to be a commensal after it was identified in the skin, lung aspirates, and gingiva from healthy individuals (311-313), although this has recently been refuted (314). At the time of writing this report, there were 109 different Nocardia species with confirmed names according to the List of Prokaryotic names with Standing Nomenclature (LPSN) (https://www.bacterio.net). Among them, 54 had been reported to cause disease in humans (315). We have seen that 23 different species cause disease in otherwise healthy individuals (Table 3). Nowadays, the guidelines for identifying Nocardia up to the species without ambiguity suggest a combination of MALDITOF mass spectrometry, gene sequencing, and, ultimately, genome sequencing (315). Using these methods, during the last decades, what was thought to be an individual species, like Nocardia asteroides, has been found to be composed of different species to the point that $N$. asteroides is no longer a valid nomenclature $(315,316)$. Unfortunately, most diagnostic labs do not have these capabilities, so $N$. asteroides is still considered in the clinical setting.

\section{DIAGNOSIS}

Multiple proteins from N. asteroides and brasiliensis have been described as being specifically recognized by patients who have suffered nocardiosis but not by healthy controls (317321). These serologic tests are not commercially available, and 


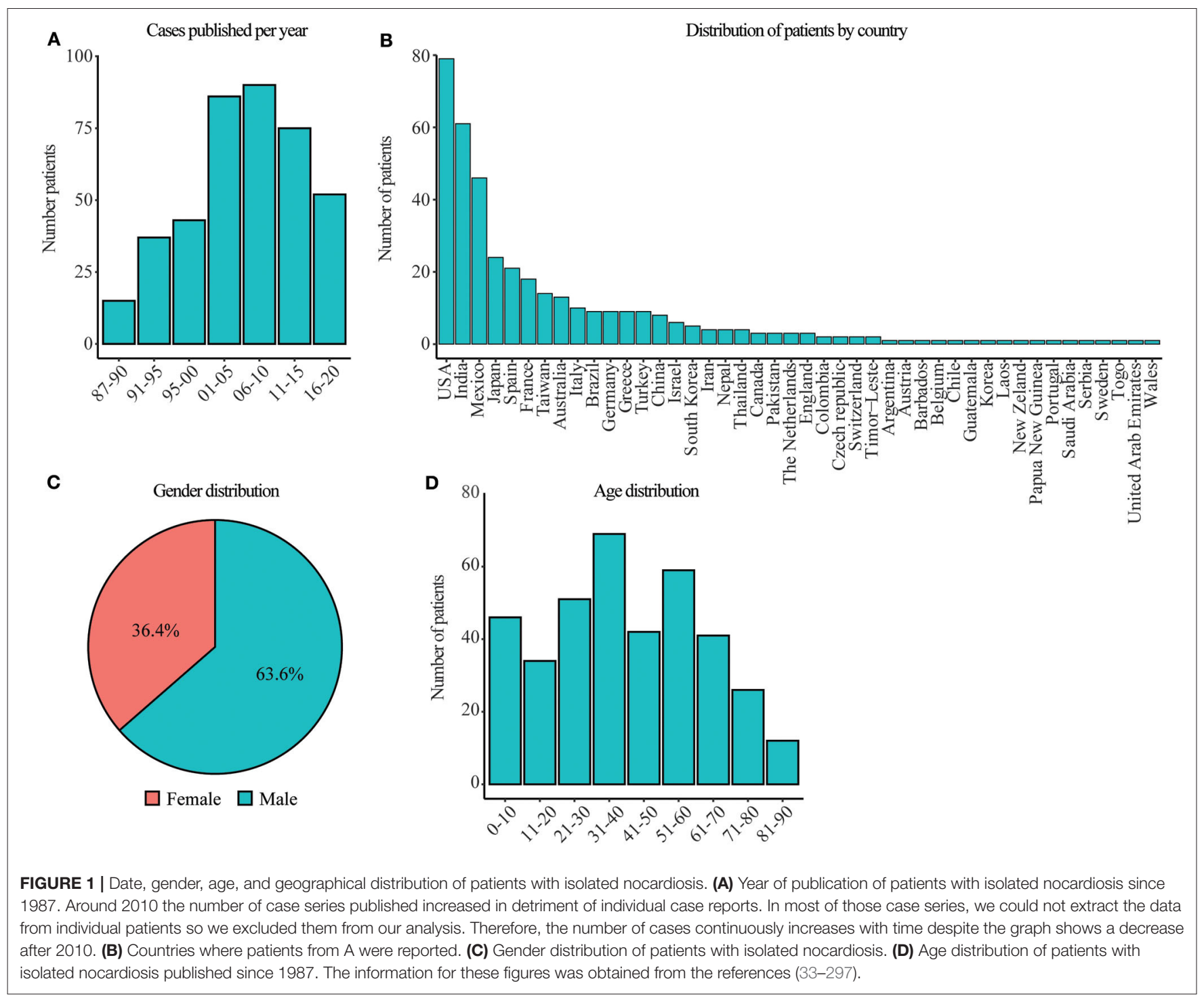

the ones described are unreliable, making clinical diagnosis difficult (322). The observation of the symptoms and other physical tests like radiologic images may be suggestive of the disease (322). However, observation of Nocardia in cultures is necessary to confirm the diagnosis (309). Identification of the pathogen occurs by growing the clinical specimen (sputum, bronchoalveolar lavage, pleural effusion, pus) on plates like tryptic soy blood agar at $35^{\circ} \mathrm{C}$. The identification of Nocardia is usually based on partial acid-fastness, resistance to lysozyme, and presence of chalky white colonies, dichotomous branches, and aerial hyphae (323). Colonies may appear after 2 days, but it is recommended to keep the plates in culture for up to 3 weeks since many species take longer to grow. Therefore, the prolonged incubation required to identify the bacteria that, unfortunately, many laboratories fail to follow, makes nocardiosis and underrepresented and underdiagnosed disease, especially in patients without risk factors. Despite the methodologies described above to identify Nocardia up to the specie, most diagnostic laboratories only have access to conventional biochemical tests such as tyrosine, xanthine, and hypoxanthine decomposition, growth at $45^{\circ} \mathrm{C}$, and gelatin hydrolysis (323). The most used molecular biology methods that are found in a diagnostic lab to identify different Nocardia spp. are gene sequencing of $16 \mathrm{~S}$ rRNA or hsp65. With these limitations in mind and considering that some patients described in this review were diagnosed up to 35 years ago, the most frequently identified species in patients with isolated nocardiosis are; $N$. brasiliensis, $N$. asteroids, $N$. farcinica, $N$. otodiscaviarum, $N$. transvalensis and N. Beijinensis (Figure 2D) (Table 3). Around $90 \%$ of cases of $N$. brasiliensis are cutaneous, consistent with what was observed in immunocompromised patients (324). However, the other five species cause cutaneous, pulmonary, or keratitis, with frequencies proportional to their identification in clinical specimens (Figure 2D). This contradicts the notion observed in immunocompromised individuals suggesting that $N$. brasiliensis causes cutaneous disease while $N$. asteroides causes 


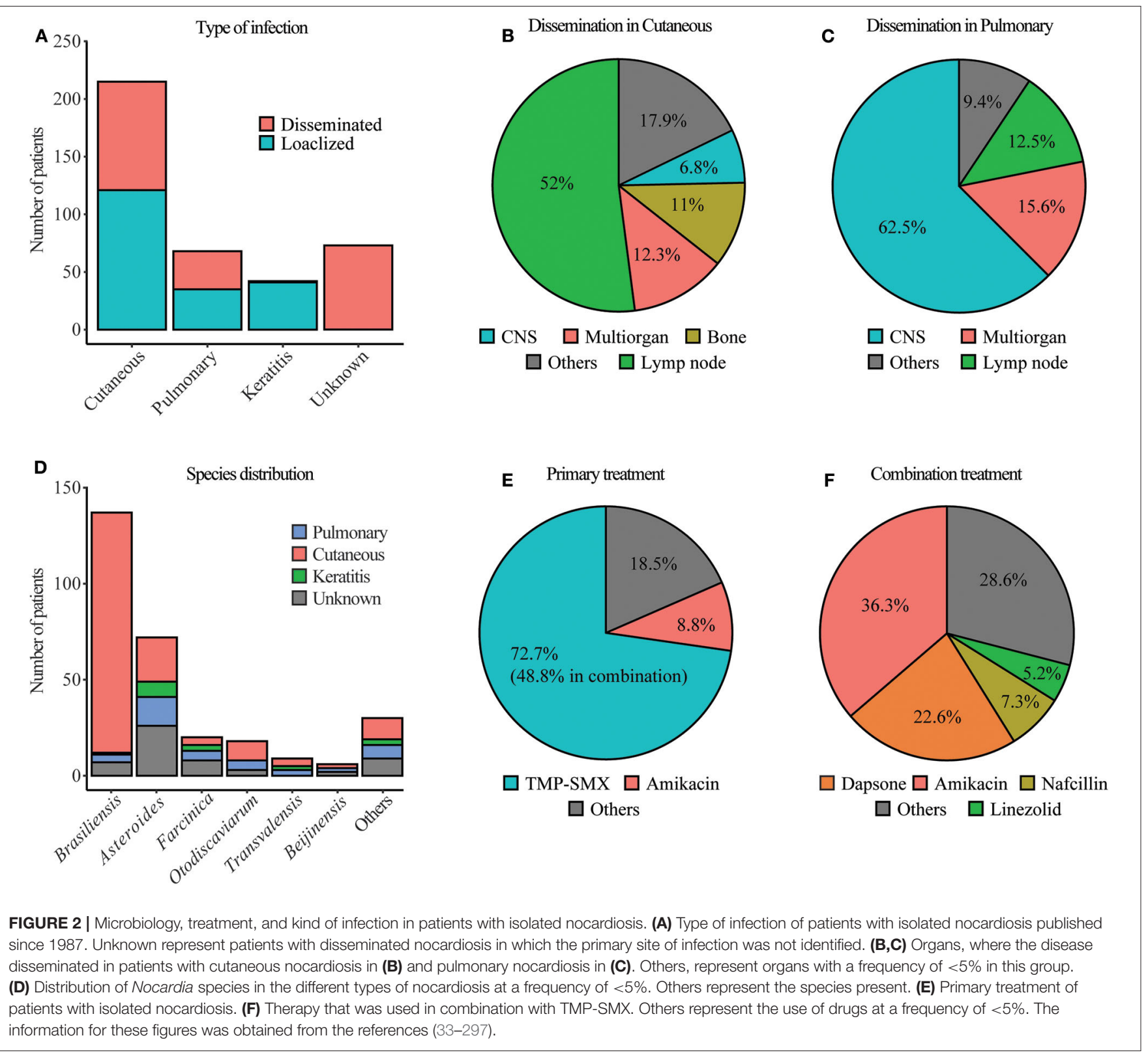

pulmonary disease (324). The lack of clinical, epidemiological, and laboratory data undermines the significance of Nocardia spp. as a potential pathogen and causes a delay in the start of appropriate treatment (325). Sometimes the diagnosis only happens post mortem, highlighting the importance and necessity of improving the diagnosis methodologies and better understanding the causes of nocardiosis in these patients without risk factors (326).

\section{TREATMENT AND OUTCOME}

Treatment for nocardiosis has been evolving since the early 20th century. The first successful treatment of a patient with nocardiosis was described in 1907 by Musgrave and Clegg in a 30-year-old woman with mycetoma. Treatment consisted of amputating the affected extremity (327). Since then, only two more patients were successfully treated until the 40 s $(328,329)$. After 1943, an increasing number of survivors were reported due to the use of the first antibiotics (sulfanilamide, penicillin, streptomycin, aureomycin), sulfonamides, and surgical incision and drainage (5). Until sulfonamide therapy became available, the mortality observed in patients with nocardiosis was $76 \%$. After its implementation, mortality dropped to $46 \%$ (6). Nowadays, sulfonamides are the drug of choice, despite the first attempt at using them to treat nocardiosis in 1937 was unsuccessful (330). The first successful treatment of nocardiosis with sulfonamides happened a few years after in 1943 (331). 
TABLE 3 | Count of the different Nocardia species identified in patients with isolated nocardiosis.

\begin{tabular}{|c|c|}
\hline Pathogen & $n$ \\
\hline N. brasiliensis & 137 \\
\hline N. asteroides & 68 \\
\hline N. farcinica & 20 \\
\hline N. otitidiscaviarum & 18 \\
\hline N. transvalensis & 9 \\
\hline N. beijingensis & 6 \\
\hline N. nova & 5 \\
\hline N. abscessus & 5 \\
\hline N. wallacei & 3 \\
\hline N. paucivorans & 3 \\
\hline N. takedensis & 2 \\
\hline N. elegans & 2 \\
\hline N. cyriacigeorgica & 2 \\
\hline N. asiatica & 2 \\
\hline N. yamanashiensis & 1 \\
\hline N. vinacea & 1 \\
\hline N. puris & 1 \\
\hline N. pseudobrasiliensis & 1 \\
\hline N. harenae & 1 \\
\hline N. crassostrea & 1 \\
\hline N. caviae & 1 \\
\hline N. arthritidis & 1 \\
\hline N. aobensis & 1 \\
\hline
\end{tabular}

In the mid-70s, patients started to be successfully treated with a 1:5 proportion of the dihydrofolate reductase inhibitor trimethoprim and the sulfonamide antibiotic sulfamethoxazole. This combination of drugs is known as TMP-SMX or cotrimoxazole. TMP-SMX has the advantage that it easily reaches antibacterial concentrations in the lung, blood, and central nervous system (332). Despite the question of whether TMPSMX treatment was more effective than sulfonamides was controversial (333), it became the treatment of choice. It was thought that all Nocardia strains are susceptible to these drugs (334); however, this is not the case, and susceptibility testing should be performed before starting the treatment (335), given that resistance is specie specific $(336,337)$. Besides, some people are allergic to TMP-SMX, which is sometimes observed after treatment starts with the additional risk that this brings for the patient (338). The standards dictate that for cutaneous disease, TMP-SMX should be administered for 1-3 months, for pulmonary disease during 6-12 months, and for disseminated, especially CNS infection, it should be of 12 months sometimes, even more, depending on the progress of the disease (339). The long treatment necessary to cure nocardiosis with TMP-SMX highlights the commonly induced side effects such as nausea, vomiting, diarrhea, gingival hyperplasia (340), acute pancreatitis (341), myelosuppression, hepatoxicity, and renal insufficiency $(308,338)$ among others. Seventy-two percent of patients with isolated nocardiosis were treated with TMP-SMX, $8 \%$ with the aminoglycoside antibiotic, Amikacin, and the last 18\% with other drugs such as the beta-lactam antibiotic imipenem or the penicillin antibiotic nafcillin among others (Figure 2E). In some cases, the treatment occurred only with one drug; however, about half of the patients treated with TMP-SMX had this treatment combined with other medications. This combination therapy involved Amikacin in 36\% of the cases, dapsone in $22 \%$, the beta-lactam antibiotic Nafcillin in $7 \%$ of the cases, and the oxazolidinone Linezolid in 5\% of cases (Figure 2F). The way of administration of the drug varied depending on the kind of disease. In cutaneous or keratitis patients, the treatment was administered mostly topically, while in pulmonary or disseminated, the antibiotics were ingested. In the most severe cases, the medication was injected intravascularly. Antibiotic treatment was used in combination with surgical intervention in $18.3 \%$ of cases. Most surgeries consisted of debridement or drainage of affected areas in the lymph nodes, CNS, lungs, or extremities, although other interventions such as limb amputation were observed. Despite treatment, in $23.1 \%$ of patients, the disease could not be cured, becoming chronic, the disease recurred after the first episode was thought to be resolved, or the patients had sequelae such as impaired vision, neurological impairment, limb amputation, or severe scarring. Besides, an overall $5.7 \%$ of the patient died due to complications caused by nocardiosis. The outcome of these patients gives an idea of the severity of this disease even with appropriate treatment in patients that do not have any additional comorbidity. It also showcases the importance of early diagnosis and the need for better diagnostic and treatment options of isolated nocardiosis.

\section{HUMAN IMMUNITY TO NOCARDIA SPP.}

Reports investigating how the human immune system fights Nocardia spp. are scarce. However, the study of patients treated with immunosuppressive drugs, anti-cytokine antibody, and information obtained from patients with PIDs has given us a clue of how such immunity is orchestrated (Tables 2, 4). PIDs are a group of diseases caused by single-gene inborn errors of immunity that impair specific cell-types or pathways of the immune system and are characterized by severe infection. The study of these diseases carried out during the last few decades has allowed us to delineate what are the critical and non-redundant cell-types and pathways in immunity against given pathogens (342). By analyzing what PIDs curse with nocardiosis, we can infer some of these anti-Nocardia immune mechanisms. The first PID in which nocardiosis was observed was chronic granulomatous disease (CGD). CGD is characterized by the impaired capacity of phagocytes to produce reactive oxygen species and, therefore, kill certain bacteria, especially catalase-positive ones (343). Early after the description of CGD, pulmonary nocardiosis started to be identified as one of the common infections suffered by these groups of patients (1517). Since then, numerous reviews and cohort studies have shown the presence of nocardiosis among patients with CGD (343-347). From these groups of PID patients, we have been able to infer that phagocytes play a critical role in human 
TABLE 4 | Treatments that affect the immune system and predispose to nocardiosis.

\begin{tabular}{|c|c|c|}
\hline Treatment & $\begin{array}{l}\text { Immunological } \\
\text { consequence }\end{array}$ & Examples of diseases treated \\
\hline Anti-BTK & Reduces B cell activation & $\begin{array}{l}\text { Hematologic malignancies such as } \\
\text { chronic lymphocytic leukemia } \\
\text { (CLL). }\end{array}$ \\
\hline Anti-CD3 & Reduces $T$ cell activation & Solid organ transplant rejection. \\
\hline Anti-CTLA-4 & Enhances T cell immunity & Melanoma, carcinoma. \\
\hline Anti-CD52 & $\begin{array}{l}\text { Depletes peripheral blood } \\
\text { lymphocytes }\end{array}$ & Multiple sclerosis, CLL. \\
\hline Steroid & Reduces cellular immunity & $\begin{array}{l}\text { Organ transplant rejection, asthma, } \\
\text { allergies, dermatitis, Crohn's } \\
\text { disease, } \\
\text { rheumatoid arthritis. }\end{array}$ \\
\hline Anti-TNF & Blocks of TNF signaling & $\begin{array}{l}\text { Inflammatory bowel disease, } \\
\text { Crohn's disease, rheumatoid } \\
\text { arthritis. }\end{array}$ \\
\hline Anty-IL12p40 & $\begin{array}{l}\text { Blocks IL-12 and IL-23 } \\
\text { signaling }\end{array}$ & $\begin{array}{l}\text { Inflammatory bowel disease, } \\
\text { Crohn's disease, psoriasis. }\end{array}$ \\
\hline Chemotherapy & $\begin{array}{l}\text { Affects the bone marrow } \\
\text { reducing cellular immunity }\end{array}$ & Cancer. \\
\hline
\end{tabular}

immunity to Nocardia spp. Furthermore, it has been shown that human-derived alpha-defensins from neutrophils can kill certain strains of Nocardia, including farcinica, nova, and asteroides strengthening the evidence of the role of neutrophils in antiNocardia immunity (348).

B cells and antibody-mediated immunity seems to be important in immunity against Nocardia spp. In patients with mycetoma, IgG1, 2, 3, 4, and $\mathrm{M}$ are higher than those in controls, suggesting an antibody response against Nocardia spp. (349). Interestingly, some patients with hematologic malignancies treated whit anti-BTK therapy develop this disease, highlighting the importance of B cells (350). Antibody disorders have also been described in patients with nocardiosis. In 1977, two cases of nocardiosis were described in patients with hypogammaglobulinemia. This disease consists of a reduction in the titers of antibodies and hence impaired immune response $(13,14)$. Similarly, a nocardiosis patient with common variable immunodeficiency consisting of deficient levels of IgG, IgA, and IgM was reported (18). Finally, one pediatric patient with hyper IgE syndrome, a disease characterized by elevated serum IgE level, chronic dermatitis, intense pruritus, and severe recurrent infection, died due to Nocardia infection (351). Despite the mechanisms in which B cells and antibody-mediated responses contribute to immunity to Nocardia spp. is not well-understood; the clinical evidence showcases the role of $\mathrm{B}$ cell-mediated immunity in fending off Nocardia spp.

The observation that patients who have AIDS develop nocardiosis made evident early on that $\mathrm{T}$ cells are essential to keep Nocardia at bay (22-24). Nocardia spp. infection is usually seen in these patients when $\mathrm{CD}^{+}$counts drop to 35 cells/ $\mu 1$ (352). Consistently, two patients with $\mathrm{CD}^{+} \mathrm{T}$ cell lymphocytopenia that developed pulmonary and CNS nocardiosis have been reported $(353,354)$. Similarly, dampened cellular immunity in patients treated with corticosteroids longterm also predisposes to nocardiosis (355). Furthermore, treatments that block cell mediated immunity such as CD3 (OKT3) or CD52 in the treatment of autoimmune and autoinflammatory diseases, have also been shown to predispose to nocardiosis (356-358). Finally, a severe combined immunodeficiency patient lacking B and T cells with a Nocardia infection has been reported (111). These studies confirm the role of $\mathrm{T}$ cells in immunity against Nocardia and suggest that $\mathrm{CD} 4^{+}$ $\mathrm{T}$ cells play a pivotal role in such immunity.

Specific cytokines have also been implicated in human immunity to Nocardia spp. It has been observed that PBMCs from patients with mycetoma caused by $N$. brasiliensis show low IFN- $\gamma$ production when stimulated with $N$. brasiliensis lysates ex vivo but a high concentration of IL-4, IL-10, IL-12, and TNF making the authors suggest at $\mathrm{T}_{\mathrm{H}} 2$ response (359). The widespread use of blocking antibodies against cytokines for therapy of autoimmune and autoinflammatory diseases, confirmed the importance of TNF to fight Nocardia spp. Some patients under treatment with anti-TNF antibodies used to treat Crohn's disease (360) or inflammatory bowel disease (361) to develop nocardiosis as a complication. More extensive studies of cohorts of patients with different conditions, all treated with anti-TNF, confirmed that the blockade of TNF causes nocardiosis in a percentage of those patients $(362,363)$. AntiIL-12p40 therapy (Blocking both IL-12 and IL-23) also used for inflammatory diseases such as inflammatory bowel disease has been described to cause nocardiosis in a patient from Australia (364). The vital role of these two cytokines, IL-12 and IL-23, in immunity against Nocardia spp. was confirmed by studying patients with IL-12R $\beta 1$ and IL-12p40 complete deficiencies. These two deficiencies abolish both IL-12 and IL23 signaling and are genetic etiologies of MSMD. Patients with MSMD display a selective susceptibility to infection by weakly virulent mycobacteria (26). A group of patients with either IL$12 \mathrm{p} 40$ or IL-12R $\beta 1$ complete deficiency has been described to curse with nocardiosis combined with Mycobacteria, Salmonella, or Klebsiella. This shows the importance of IL-12 and or IL-23 in immunity against Nocardia spp. (365-368). Furthermore, in a set of mixed lymphocyte reaction experiments with $N$. farcinica, the authors showed that monocyte-derived DCs co-cultured with T cells are capable of producing high levels of TNF and IL-23 and eliminate engulfed $N$. farcinica. This experiment corroborates the importance of IL-23 and suggests that DCs contribute to fighting Nocardia (369). Besides, some nocardiosis patients with, a priori, no additional risk factor, have been found to produce neutralizing anti-GM-CSF auto-antibodies (370). Overall, the combination of clinical, pharmacological, immunological, and genetic evidence indicates that TNF, GM-CSF, IL-12, and or IL-23 are essential players in immunity against Nocardia spp.

\section{CONCLUDING REMARKS, IS NOCARDIOSIS A PID?}

Although nocardiosis is considered a disease of immunocompromised individuals, the evidence shows that 
individuals, a priory healthy, can also have this disease. The description of such patients has been growing during recent decades, although it is still considered to be underestimated. In this group of patients, the disease is less severe than in immunocompromised individuals. However, even after appropriate treatment, mortality, and morbidity are high. Sometimes this is due to the late diagnosis and late application of the treatment given that this disease is not considered in the differential diagnosis in patients without risk factors. Besides, TMP-SMX, the most frequently used therapy in this group of patients, has numerous side effects. Therefore, the study of patients with isolated nocardiosis is necessary to better understand the causes and pathophysiology of this disease, which will improve its diagnosis and treatment. During the past two decades, the notion that severe infectious disease in patients otherwise healthy can arise from single-gene inborn errors of immunity has taken steam $(27,28)$. The genetic dissection of diseases such as MSMD (26), human papillomavirus-associated epidermodysplasia verruciformis (29), invasive pneumococcal disease (371), invasive dermatophytic disease (372), or chronic mucocutaneous candidiasis (32) among others, have shown that mutations in one gene can cause a selective susceptibility to one specific kind of pathogens. That has allowed scientists and physicians to delineate the critical and non-redundant players in immunity against that given pathogen and propose preventive treatment to individuals at risk as well as genetic diagnosis and

\section{REFERENCES}

1. Nocard EIE. Note sur la maladie des boeufs de la Guadeloupe, connue sous le nom de farcin. Ann Inst Pasteur. (1888) 293-302.

2. Trevisan. I Generi e le Specie delle Batteriacee. Milano: Tipo-lit, Zanaboni e Gabuzzi (1889)

3. Eppinger H. Ueber eine neue pathogenic Cladothrix und eine durch sie hervorgerufene Pseudotuberculosis. Wien Klin Wochenschr. (1890) 3: 321-3.

4. Waksmana SA, Henricib AT. The nomenclature and classification of the actinomycetes. J Bacteriol. (1943) 46:337-41. doi: 10.1128/JB.46.4.337-341.1943

5. Cruz PT, Clancy CF. Nocardial osteomyelitis and septicemia. Am J Pathol. (1952) 28:607-27.

6. Murray JF, Finegold SM, Froman S, Will DW. The changing spectrum of nocardiosis. a review and presentation of nine cases. Am Rev Respir Dis. (1961) 83:315-30. doi: 10.1164/arrd.1961.83.3.315

7. Seeliger H, Lange J. Nocardiosis in the final stage of Hodgkin's disease. $Z$ Tropenmed Parasitol. (1954) 3:356-62.

8. Beeson PB. Nocardiosis as a complication of pulmonary alveolar proteinosis. Ann Intern Med. (1964) 60:314. doi: 10.7326/0003-4819-602-314

9. Kerbel NC. Long-term steroid therapy of the nephrotic syndrome in an adult complicated by fatal nocardiosis. Can Med Assoc J. (1962) 87:129-32.

10. Whitmore DN, Gresham GA, Grayson MJ. Nocardiosis in anaemic patients given steroids. J Clin Pathol. (1961) 14:259-63. doi: 10.1136/jcp.14. 3.259

11. Danowski TS, Cooper WM, Braude A. Cushing's syndrome in conjunction with Nocardia asteroides infection. Metabolism. (1962) 11:265-72.

12. Hill RB Jr, Rowlands DT Jr, Rifkind D. Infectious pulmonary disease in patients receiving immunosuppressive therapy for organ transplantation. $N$ Engl J Med. (1964) 271:1021-7. doi: 10.1056/NEJM196411122712001

13. Murray KJ, Ackerman SK, Chou SN, Douglas SD. Hypogammaglobulinemia and Nocardia brain abscesses. Neurosurgery. (1977) 1:297-9. doi: 10.1227/00006123-197711000-00015 counseling for patients and families. Nocardiosis shows some similarities with the diseases mentioned above since it is also caused by a weakly virulent pathogen of ubiquitous exposure. Patients with a weakened immune system are more susceptible and given that outbreaks only occur among immunosuppressed individuals shows that exposure to Nocardia spp. is necessary, but a host predisposition is also needed. Therefore, isolated nocardiosis may be an undiagnosed PID caused by a singlegene inborn error of immunity that can explain its selective susceptibility to Nocardia spp. infection. To test this hypothesis and to try to improve the diagnosis and treatment of this group of patients, we are recruiting patients with isolated nocardiosis to identify the genetic and immunological causes of this disease.

\section{AUTHOR CONTRIBUTIONS}

RM-B did the literature research, analyzed, and graphed the data and wrote the manuscript.

\section{ACKNOWLEDGMENTS}

RM-B would like to thank Janet Markle (VUMC), Sergio M. Pontejo (NAIAID, NIH), Jean-Laurent Casanova (The Rockefeller University), Jacinta Bustamante (Université Paris Descartes) for editorial assistance and critical reading.

14. Sher NA, Hill CW, Eifrig DE. Bilateral intraocular Nocardia asteroides infection. Arch Ophthalmol. (1977) 95:1415-8. doi: 10.1001/archopht.1977.04450080125015

15. Stites DP, Glezen WP. Pulmonary nocardiosis in childhood. a case report. Am J Dis Child. (1967) 114:101-5. doi: 10.1001/archpedi.1967.020902201 07020

16. Glezen WP. Infection and chronic granulomatous disease. J Pediatr. (1974) 84:160-1, author reply 161. doi: 10.1016/S0022-3476(74)8 0587-1

17. Good RA, Quie PG, Windhorst DB, Page AR, Rodey GE, White J, et al. Fatal (chronic) granulomatous disease of childhood: a hereditary defect of leukocyte function. Semin Hematol. (1968) 5:215-54.

18. Singh S, Samant R, Rodrigues C. Nocardiosis in a patient with common variable immunodeficiency. J Assoc Physicians India. (2006) 54:495-6. Available at: https://www.ncbi.nlm.nih.gov/pubmed/16909702

19. Saltzman HA, Chick EW, Conant NF. Nocardiosis as a complication of other diseases. Lab Invest. (1962) 11:1110-7.

20. Utz JP. The spectrum of opportunistic fungus infections. Lab Invest. (1962) 11:1018-25.

21. Cross RM, Binford CH. Is nocardia asteroides an opportunist? (1962) 11:1103-9.

22. Sharer LR, Kapila R. Neuropathologic observations in acquired immunodeficiency syndrome (AIDS). Acta Neuropathol. (1985) 66:188-98. doi: $10.1007 /$ BF00688583

23. Rodriguez JL, Barrio JL, Pitchenik AE. Pulmonary nocardiosis in the acquired immunodeficiency syndrome. diagnosis with bronchoalveolar lavage and treatment with non-sulphur containing drugs. Chest. (1986) 90:912-4. doi: 10.1378/chest.90.6.912

24. Adair JC, Beck AC, Apfelbaum RI, Baringer JR. Nocardial cerebral abscess in the acquired immunodeficiency syndrome. Arch Neurol. (1987) 44:548-50. doi: 10.1001/archneur.1987.00520170074026

25. Beaman BL, Burnside J, Edwards B, Causey W. Nocardial infections in the United States, 1972-1974. J Infect Dis. (1976) 134:286-9. doi: 10.1093/infdis/134.3.286 
26. Bustamante J. Mendelian susceptibility to mycobacterial disease: recent discoveries. Hum Genet. (2020) 139:993-1000. doi: 10.1007/s00439-020-02120-y

27. Casanova JL. Severe infectious diseases of childhood as monogenic inborn errors of immunity. Proc Natl Acad Sci USA. (2015) 112:E7128-37. doi: $10.1073 /$ pnas. 1521651112

28. Casanova JL. Human genetic basis of interindividual variability in the course of infection. Proc Natl Acad Sci USA. (2015) 112:E7118-27. doi: 10.1073/pnas.1521644112

29. de Jong SJ, Imahorn E, Itin P, Uitto J, Orth G, Jouanguy E, et al. Epidermodysplasia verruciformis: inborn errors of immunity to human beta-papillomaviruses. Front Microbiol. (2018) 9:1222. doi: $10.3389 /$ fmicb.2018.01222

30. Picard C, Puel A, Bonnet M, Ku CL, Bustamante J, Yang K, et al. Pyogenic bacterial infections in humans with IRAK-4 deficiency. Science. (2003) 299:2076-9. doi: 10.1126/science.1081902

31. Lanternier F, Pathan S, Vincent QB, Liu L, Cypowyj S, Prando C, et al. Deep dermatophytosis and inherited CARD9 deficiency. N Engl J Med. (2013) 369:1704-14. doi: 10.1056/NEJMoa1208487

32. Okada S, Puel A, Casanova J-L, Kobayashi M. Chronic mucocutaneous candidiasis disease associated with inborn errors of IL-17 immunity. Clin Transl Immunol. (2016) 5:e114. doi: 10.1038/cti.2016.71

33. Abu-Gazala M, Engel A, Stern A, Guralnik L. An unusual case of nocardiosis presented as a mediastinal mass in an immunocompetent patient. Am J Respir Crit Care Med. (2014) 189:492-3. doi: 10.1164/rccm.201308-1546LE

34. Agrawal SM, Raut SS. Primary cutaneous disease due to Nocardia asteroides in an immunocompetent host. Ind J Pathol Microbiol. (2011) 54:185-6. doi: 10.4103/0377-4929.77399

35. Al Soub H, Almaslamani M, Al Khuwaiter J, El Deeb Y, Abu Khatab M. Primary Nocardia meningitis in a patient without a predisposing condition: case report and review of the literature. Scand J Infect Dis. (2007) 39:737-41. doi: 10.1080/00365540701199873

36. Al Tawfiq JA, Mayman T, Memish ZA. Nocardia abscessus brain abscess in an immunocompetent host. J Infect Public Health. (2013) 6:158-61. doi: 10.1016/j.jiph.2012.11.012

37. Alavi Darazam I, Shamaei M, Mobarhan M, Ghasemi S, Tabarsi P, Motavasseli M, et al. Nocardiosis: risk factors, clinical characteristics and outcome. Iran Red Cresc Med J. (2013) 15:436-9. doi: 10.5812/ircmj.2384

38. Alp E, Yildiz O, Aygen B, Sumerkan B, Sari I, Koc K, et al. Disseminated nocardiosis due to unusual species: two case reports. Scand J Infect Dis. (2006) 38:545-8. doi: 10.1080/00365540500532860

39. Amatya R, Koirala R, Khanal B, Dhakal S. Nocardia brasiliensis primary pulmonary nocardiosis with subcutaneous involvement in an immunocompetent patient. Ind J Med Microbiol. (2011) 29:68-70. doi: $10.4103 / 0255-0857.76530$

40. Ameen M, Vargas F, Arenas R, Mercado, E. V. del. Successful treatment of Nocardia actinomycetoma with meropenem and amikacin combination therapy. Int J Dermatol. (2011) 50: 443-5. doi: 10.1111/j.1365-4632.2010.04748.x

41. Aozasa N, Kiso M, Kaneko T. Primary lymphocutaneous nocardiosis due to Nocardia brasiliensis which was successfully treated with only oral potassium iodide. J Dermatol. (2011) 38:826-8. doi: 10.1111/j.1346-8138.2010.01074.x

42. Arenas R, Ameen M. Giant grains of Nocardia actinomycetoma. Lancet Infect Dis. (2010) 10:66. doi: 10.1016/S1473-3099(09)70347-0

43. Arias-Miranda IM, Nuno-Mateo FJ, Viejo De La Guerra G, GarciaAlcalde ML. Nocardiosis. Enferm Infec Microbiol Clin. (2005) 23:637-38. doi: 10.1016/S0213-005X(05)75050-3

44. Asmar BI, Bashour BN. Septic arthritis due to nocardia asteroides. South Med J. (1991) 84:933-4. doi: 10.1097/00007611-199107000-00032

45. Astudillo L, Dahan S, Escourrou G, Sailler L, Carreiro M, Ollier S, et al. Cat scratch responsible for primary cutaneous Nocardia asteroides in an immunocompetent patient. Br J Dermatol. (2001) 145:684-5. doi: 10.1046/j.1365-2133.2001.04447.x

46. Babayigit A, Olmez D, Sozmen SC, Makay B, Uzuner N, Karaman $\mathrm{O}$, et al. Infection caused by Nocardia farcinica mimicking pulmonary metastasis in an adolescent girl. Pediatric Emerg Care. (2010) 26:203-5. Retrieved from: https://journals.lww.com/peconline/Fulltext/2010/03000/ Infection_Caused_by_Nocardia_farcinica_Mimicking.7.aspx
47. Baghdadlian H, Sorger S, Knowles K, McNeil M, Brown J. Nocardia transvalensis pneumonia in a child. Pediatr Infect Dis J. (1989) 8:470-1. doi: 10.1097/00006454-198907000-00012

48. Bajracharya L, Gurung R. A case of nocardia keratitis treated successfully with topical amikacin. Nepal J Ophthal. (2012) 4:170-3. doi: 10.3126/nepjoph.v4i1.5870

49. Banashankari GS, Rudresh HK, Sreeja S, Beena. Nocardial mycetoma: reinfection with a different species at an unusual site - a rare case. Ind J Pathol Microbiol. (2013) 56: 333-334. doi: 10.4103/0377-4929.120424

50. Bandeira ID, Guimaraes-Silva P, Cedro-Filho RL, de Almeida VRP, Bittencourt AL, Brites C. Primary cutaneous nocardiosis. J Deutschen Dermatol. (2019) 17:327-9. doi: 10.1111/ddg.13770

51. Baraboutis IG, Argyropoulou A, Papastamopoulos V, Psaroudaki Z, Paniara O, Skoutelis AT. Primary sternal osteomyelitis caused by Nocardia nova: case report and literature review. Brazil J Infect Dis. (2008) 12:257-9. doi: 10.1590/S1413-86702008000300018

52. Barbara Gomila S, Susana Sabater V, Jesus Merino P, Rafael Igual A, Rosario Moreno M. Absceso cerebral por Nocardia nova. Rev Chil Infectol. (2012) 29:112-3. doi: 10.4067/S0716-10182012000100019

53. Baroni MR, Norona M, Ronchi S, Mayoral C. Necrotizing lymphadenitis caused by Nocardia asteroides in a healthy girl. Rev Argen Microbiol. (2004) 36:75-7.

54. Battista AJ, Huysman J, Cunha BA. Nocardia brasiliensis leg ulcer in a child. Pediatr Infect Dis J. (1990) 9:370-1. doi: 10.1097/00006454-199005000-00014

55. Behaegel J, Ni Dhubhghaill S, Koppen C. Diagnostic challenges in nocardia keratitis. Eye Contact Lens. (2018) 44:S370-2. doi: 10.1097/ICL.0000000000000462

56. Benes J, Viechova J, Picha D, Horova B, Zatloukal P. Disseminated Nocardia asteroides infection in an immunocompetent woman following an arm injury. Infection. (2003) 31:112-4. doi: 10.1007/s15010-003-3073-x

57. Bernal E, Ahmad N, Lopez P, Gutierrez F. Sindrome linfocutaneo por Nocardia brasiliensis en una paciente inmunocompetente. Enferm Infec Microbiol Clin. (2008) 26:58-60. doi: 10.1157/13114398

58. Beuret F, Schmitt E, Planel S, Lesanne G, Bracard S. Subtentorial cerebral nocardiosis in immunocompetent patients: $\mathrm{CT}$ and MR imaging findings. Diag Intervent Imag. (2015) 96:953-7. doi: 10.1016/j.diii.2015.03.010

59. Bharathi MJ, Ramakrishnan R, Meenakshi R, Vasu S. Nocardia asteroides canaliculitis: a case report of uncommon aetiology. Ind J Med Microbiol. (2004) 22:123-5.

60. Bhusal B, Kumar A, Prajna MV, Srinivasan M. Nocardia keratitis following penetrating corneal injury treated with topical ampicillin. Nepal J Ophthalmol. (2016) 8:82-6. doi: 10.3126/nepjoph.v8i1.16143

61. Bonifaz, A, Flores P, Saul A, Carrasco-Gerard E, Ponce RM. Treatment of actinomycetoma due to Nocardia spp. with amoxicillin-clavulanate. $\mathrm{Br} \mathrm{J}$ Dermatol. (2007) 156:308-11. doi: 10.1111/j.1365-2133.2006.07557.x

62. Bonifaz, Alexandro, Espinosa-Diaz S, Argaez J, Hernandez-Castro R, Xicohtencatl- Cortes J, et al. Actinomycetoma due to Nocardia brasiliensis with extension to the ovaries. Euro J Obstet Gynecol. Reprod Biol. (2017) 211:224-5. doi: 10.1016/j.ejogrb.2017.02.023

63. Bonifaz, Alexandro, Ibarra G, Saul A, Paredes-Solis V, Carrasco-Gerard E, et al. Mycetoma in children: experience with 15 cases. Pediatr Infect Dis J. (2007) 26. Retrieved from: https://journals.lww.com/pidj/fulltext/2007/ 01000/mycetoma_in_children_experience_with_15_cases.11.aspx

64. Borm W, Gleixner M. Nocardia brain abscess misinterpreted as cerebral infarction. J Clin Neurosci. (2003) 10:130-2. doi: 10.1016/S0967-5868(02)00121-2

65. Bosamiya SS, Vaishnani JB, Momin AM. Sporotrichoid nocardiosis with cutaneous dissemination. Ind J Dermatol Venereol Leprol. (2011) 77:535. doi: 10.4103/0378-6323.82409

66. Bottei E, Flaherty JP, Kaplan LJ, Duffee-Kerr L. Lymphocutaneous Nocardia brasiliensis infection transmitted via a cat scratch: a second case. Clin Infect Dis. (1994) 18:649-50. doi: 10.1093/clinids/18.4.649

67. Brannan PA, Kersten RC, Hudak DT, Anderson HK, Kulwin DR. Primary Nocardia brasiliensis of the eyelid. Am J Ophthalmol. (2004) 138:498-9. doi: 10.1016/j.ajo.2004.04.020

68. Brecker SJ, Pugey CD. Nocardia asteroides infection of the cauda equina. J Neurol Neurosurg Psychiatry. (1988) 51:309-11. doi: 10.1136/jnnp. 51.2.309 
69. Cakir E, Buyukpinarbasili N, Ziyade S, Selcuk-Duru HN, Bilgin M, Topuz U. Endobronchial nocardiosis in an 11-year-old child. Pediatric Pulmonol. (2013) 48:1144-7. doi: 10.1002/ppul.22740

70. Cassir N, Million M, Noudel R, Drancourt M, Brouqui P. Sulfonamide resistance in a disseminated infection caused by Nocardia wallacei: a case report. J Med Case Rep. (2013) 7:103. doi: 10.1186/1752-1947-7-103

71. Castro JG, Espinoza L. Nocardia species infections in a large county hospital in Miami: 6 years experience. J Infect. (2007) 54:358-61. doi: 10.1016/j.jinf.2006.08.003

72. Casty FE, Wencel M. Endobronchial nocardiosis. Euro Resp J. (1994) 7:1903-5.

73. Chang P, Logemann H. Mini-mycetoma due to Nocardia brasiliensis. Int J Dermatol. (1992) 31:180-1. doi: 10.1111/j.1365-4362.1992.tb03929.x

74. Chawla K, Mukhopadhayay C, Shetty PV. First report of submandibular and parotid abscess due to Nocardia asteroides. Brazil J Infect Dis. (2010) 14:544-5. doi: 10.1016/S1413-8670(10)70108-2

75. Chedid MBF, Chedid MF, Porto NS, Severo CB, Severo LC. Nocardial infections: report of 22 cases. Rev Instit Med Trop Sao Paulo. (2007) 49:23946. doi: 10.1590/s0036-46652007000400009

76. Chen K-W, Lu C-W, Huang T-C-F, Liau Y-L, Lin J-F, Li S-Y, et al. Cutaneous manifestations of Nocardia brasiliensis infection in Taiwan during 2002-2012 - clinical studies and molecular typing of pathogen by gyrB and 16S gene sequencing. Diagn Microbiol Infect Dis. (2013) 77:74-8. doi: 10.1016/j.diagmicrobio.2013.05.008

77. Chen N, Qin Q, Sun K-D, Luo D, Cheng Q-H. An unusual successful treatment with non-sulfonamides: primary cutaneous nocardiosis caused by Nocardia brasiliensis. Therap Clin Risk Manag. (2018) 14:1661-4. doi: 10.2147/TCRM.S169239

78. Chen Y-C, Lee C-H, Chien C-C, Chao T-L, Lin W-C, Liu J-W, et al. Pulmonary nocardiosis in southern Taiwan. J Microbiol Immunol Infect. (2013) 46:441-7. doi: 10.1016/j.jmii.2012.07.017

79. Chung YL, Park JC, Takatori K, Lee KH. Primary cutaneous nocardiosis mimicking lupus erythematosus. Br J Dermatol. (2001) 144:639-41. doi: 10.1046/j.1365-2133.2001.04110.x

80. Comellas J, Morales M, Granell F. Nodular lymphangitis caused by Nocardia asteroides. Enferm Infec Microbiol Clin. (2000) 18:385-8.

81. Cooper CJ, Said S, Popp M, Alkhateeb H, Rodriguez C, Aguilar MP, et al. A complicated case of an immunocompetent patient with disseminated nocardiosis. Infect Dis Rep. (2014) 6:5327. doi: 10.4081/idr.2014.5327

82. Crozier JA, Andhavarapu S, Brumble LM, Sher T. First report of Nocardia beijingensis infection in an immunocompetent host in the United States. J Clin Microbiol. (2014) 52:2730-2. doi: 10.1128/JCM.00588-14

83. De La Iglesia P, Viejo G, Gomez B, De Miguel D, Del Valle A, Otero L. Fatal pulmonary Nocardia farcinica infection. J Clin Microbiol. (2002) 40:1098-9. doi: 10.1128/JCM.40.3.1098-1099.2002

84. Debieuvre D, Dalphin JC, Jacoulet P, Breton JL, Boiron P, Depierre A. Disseminated infection due to an unusual strain of Nocardia farcinica. Rev Mal Respir. (1993) 10:356-8.

85. Denk PO, Thanos S, Thiel HJ. Amikacin may be drug of choice in Nocardia keratitis. Br J Ophthal. (1996) 80:928-9. doi: 10.1136/bjo.80.10.928

86. Derancourt C, Theodose R, Deschamps L, Liautaud B, Briand E, Derancourt S, et al. Primary cutaneous nocardiosis caused by Nocardia beijingensis. Br J Dermatol. (2012) 167:216-8. doi: 10.1111/j.1365-2133.2012. 10832.x

87. Dias M, Nagarathna S, Mahadevan A, Chandramouli B, Chandramuki A. Nocardial brain abscess in an immunocompetent host. Ind J Med Microbiol. (2008) 26:274-7. doi: 10.4103/0255-0857.42052

88. Dikensoy O, Filiz A, Bayram N, Balci I, Zer Y, Celik G, et al. First report of pulmonary Nocardia otitidiscaviarum infection in an immunocompetent patient from Turkey. Int J Clin Pract. (2004) 58:210-3. doi: 10.1111/j.1368-5031.2004.0133.x

89. Dinulos JG, Darmstadt GL, Wilson CB, Krengel WFIII, Burns JL. Nocardia asteroides septic arthritis in a healthy child. Pediatr Infect Dis J. (1999) 18:308-10. doi: 10.1097/00006454-199903000-00026

90. Dominguez DC, Antony SJ. Actinomyces and nocardia infections in immunocompromised and nonimmunocompromised patients. J Natl Med Assoc. (1999) 91:35-9.
91. Douglas RM, Grove DI, Elliott J, Looke DFM, Jordan AS. Corneal ulceration due to Nocardia asteroides. Austr. N Zeal J Ophthal. (1991) 19:317-20. doi: 10.1111/j.1442-9071.1991.tb00679.x

92. Duran E, Soledad Salvo M, Gil J, Cachon R. Nocardiosis linfocutanea por Nocardia brasiliensis en un paciente inmunocompetente. Med Clin. (2009) 132:404-5. doi: 10.1016/j.medcli.2008.09.006

93. Eggink CA, Wesseling P, Boiron P, Meis JF. Severe keratitis due to Nocardia farcinica. J Clin Microbiol. (1997) 35:999-1001.

94. Epelboin L, Woessner J, Roussin C, Benoit-Cattin T, Noca P, Godefroy $\mathrm{C}$, et al. Actinomycetome du genou a Nocardia otitidiscaviarum aux Comores. Annal Dermatol Venereol. (2013) 140:287-90. doi: 10.1016/j.annder.2013.01.426

95. Eren E, Ulu-Kilic A, Atalay A, Demiraslan H, Parkan O, Koc N. Report of an immunocompetent case with disseminated infection due to Nocardia otitidiscaviarum: identification by $16 \mathrm{~S}$ rRNA gene sequencing. Infez Med. (2016) 24:71-6.

96. Estrada-Chavez GE, Estrada R, Fernandez R, Arenas R, Reyes A, Guevara $\mathrm{C}$, et al. Cervical and middle dorsal actinomycetomas from Guerrero State, Mexico. Int J Dermatol. (2017) 56:1146-9. doi: 10.1111/ijd.13775

97. Faccini-Martinez AA, Zanotti RL, Moraes MS, Falqueto A. Nodular lymphangitis syndrome. Am J Trop Med Hygiene. (2017) 97:1282-4. doi: 10.4269/ajtmh.17-0397

98. Farina C, Boiron P, Ferrari I, Provost F, Goglio A. Report of human nocardiosis in Italy between 1993 and 1997. Euro J Epidemiol. (2001) 17:1019-22. doi: 10.1023/A:1020010826300

99. Farina, Claudio, Andrini L, Bruno G, Sarti M, Francoise Tripodi M, et al. Nocardia brasiliensis in Italy: a nine-year experience. Scand J Infect Dis. (2007) 39:969-74. doi: 10.1080/00365540701466124

100. Farina, Claudio, Boiron P, Goglio A, Provost F. Human nocardiosis in Northern Italy from 1982 to 1992. Scand J Infect Dis. (1995) 27:23-7. doi: 10.3109/00365549509018968

101. Farran Y, Antony S. Nocardia abscessus-related intracranial aneurysm of the internal carotid artery with associated brain abscess: a case report and review of the literature. J Infect Public Health. (2016) 9:358-61. doi: 10.1016/j.jiph.2015.11.009

102. Fergie JE, Purcell K. Nocardiosis in South Texas children. Pediatr Infect Dis J. (2001) 20. Retrieved from: https://journals.lww.com/pidj/Fulltext/2001/ 07000/Nocardiosis_in_South_Texas_children.15.aspx

103. Figgis PA, Glanville AR, Harkness JL. Nocardia asteroides pneumonia with bacteraemia. Med J Austr. (2003) 179:171-2. doi: 10.5694/j.1326-5377.2003.tb05481.x

104. Fleetwood IG, Embil JM, Ross IB. Nocardia asteroides cerebral abscess in immunocompetent hosts: report of three cases and review of surgical recommendations. Surg Neurol. (2000) 53:605-10. doi: 10.1016/S0090-3019(00)00242-1

105. Flores Gonzalez L, Carballo MG, Munoz E, Dionisio de Cabalier ME. Localized nocardiosis. Rev Facul Cienc Med. (1999) 56:105-11.

106. Freiberg AA, Herzenberg JE, Sangeorzan JA. Thorn synovitis of the knee joint with Nocardia pyarthrosis. Clin Orthop Relat Res. (1993) 287:233-6. doi: 10.1097/00003086-199302000-00037

107. Freland C, Fur JL, Nemirovsky-Trebucq B, Lelong P, Boiron P. Primary cutaneous nocardiosis caused by Nocardia otitidiscaviarum: two cases and a review of the literature. J Trop Med Hyg. (1995) 98:395-403.

108. Frickmann H, Jungblut S, Bargon J, Boddinghaus B. Pneumonia induced by nocardia - a case report. Pneumologie. (2004) 58:850-3. doi: 10.1055/s-2004-830099

109. Fukuda H, Saotome A, Usami N, Urushibata O, Mukai H. Lymphocutaneous type of nocardiosis caused by Nocardia brasiliensis: a case report and review of primary cutaneous nocardiosis caused by N. brasiliensis reported in Japan. J Dermatol. 35:346-53. doi: 10.1111/j.1346-8138.2008.00482.x

110. Gadelha, VdB, Nascimento FA, Fiamoncini VK, Freitas S, Augusto Da J, Freitas S, et al. Teaching neuroimages: the tetraplegic gardener: a case of CNS nocardiosis in an immunocompetent patient. Neurology. (2019) 92:e2840-1. doi: 10.1212/WNL.0000000000007663

111. Georghiou PR, Blacklock ZM. Infection with Nocardia species in Queensland: a review of 102 clinical isolates. Med J Aust. (1992) 156:692-7. doi: 10.5694/j.1326-5377.1992.tb121509.x 
112. Gieger A, Waller S, Pasternak J. Nocardia arthritidis keratitis: case report and review of the literature. Nepal J Ophthal. (2017) 9:91-4. doi: 10.3126/nepjoph.v9i1.17543

113. Gonzalez A, Fakhar K, Gubernick D, Tuli S. Scleritis caused by in vitro linezolid-resistant Nocardia asteroides. Case Rep Ophthalmol Med. (2014) 2014:326957. doi: 10.1155/2014/326957

114. Grau Perez M, Casabella Pernas A, de la Rosa del Rey MdelP, Torrado Gonzalez R. Primary cutaneous nocardiosis: a pitfall in the diagnosis of skin infection. Infection. (2017) 45:927-8. doi: 10.1007/s15010-017-1033-0

115. Gudivada V, Gochhait D, Bhandary C, Mishra N, Siddaraju N. Cutaneous nocardiosis with discharging sinus clinically mimicking tuberculosis diagnosed by cytology. Diagn Cytopathol. (2019) 47:935-8. doi: $10.1002 /$ dc. 24217

116. Gugnani HC, Sehgal VN, Singh VK, Boiron P, Kumar S. 'Nocardia asteroides' mycetoma of the foot. J Euro Acad Dermatol Venereol. (2002) 16:640-2. doi: 10.1046/j.1468-3083.2002.00653_3.x

117. Guiral J, Refolio C, Carrero P, Carbajosa S. Sacral osteomyelitis due to Nocardia asteroids. Acta Orthop. (1991) 62:389-90. doi: 10.3109/17453679108994479

118. Gyotoku T, Kayashima K, Nishimoto K, Ono T. Cutaneous nocardiosis developing around gravel inserted during a traffic injury. J Dermatol. (2002) 29:803-9. doi: 10.1111/j.1346-8138.2002.tb00227.x

119. Hachisuka H, Ichiki M, Yoshida N, Nakano S, Sasai Y. Primary subcutaneous abscess caused by Nocardia otitidiscaviarum. J Am Acad Dermatol. (1989) 21:137-9. doi: 10.1016/S0190-9622(89)80355-X

120. Hannemann J, Dalitz M, Hell W, Lebeau A, Busch D, Dalhoff K. Generalized nocardiosis with meningoencephalitis in a nonimmunosuppressed female patient. Dtsch Med Wochenschr. (1993) 118:1281-6.

121. Harth Y, Friedman-Birnbaum R, Lefler E, Bergman R. Two patients with simultaneous, unusually located primary cutaneous nocardiosis. J Am Acad Dermatol. (1992) 26:132-3. doi: 10.1016/S0190-9622(08)80531-2

122. Hernandez-Bel P, Mayorga J, Elva Perez M. Actinomicetoma por Nocardia brasiliensis. Anal Pediatria. (2010). doi: 10.1016/j.anpedi.2010.02.021

123. Hironaga M, Mochizuki T, Watanabe S. Acute primary cutaneous nocardiosis. J Am Acad Dermatol. (1990) 23(2 Pt 2):399-400.

124. Hisatsugu K, Shigeru H, Makoto M, Iwao Y, Kazuaki Y, Takashi M. A case report of nocardiosis at the cauda equina. J Orthop Sci. (2015) 20:434-8. doi: 10.1007/s00776-013-0460-8

125. Hong SB, Han K, Son BR, Shin KS, Rim BC. First case of Nocardia nova spinal abscess in an immunocompetent patient. Brazil J Infect Dis. (2012) 16:196-9. doi: 10.1016/S1413-8670(12)70306-9

126. Hope W, Looke D. Sequential infection with Nocardia farcinica and Cryptococcus neoformans var. gattii in an immunocompetent host. J Inf. (2003) 47:256-9. doi: 10.1016/S0163-4453(03)00083-5

127. Hornef MW, Gandorfer A, Heesemann J, Roggenkamp A. Humoral response in a patient with cutaneous nocardiosis. Dermatology. (2000) 200:78-80. doi: $10.1159 / 000018325$

128. Hunter LR, Krinsky AH, Fleener CH. Preseptal cellulitis caused by Nocardia brasiliensis. Am J Ophthalmol. (1992) 114:373-4. doi: 10.1016/S0002-9394(14)71812-4

129. Ichinomiya A, Nishimura K, Takenaka M, Utani A, Nishimoto K. Mycetoma caused by Nocardia transvalensis with repeated local recurrences for 25 years without dissemination to viscera. J Dermatol. (2014) 41:556-7. doi: $10.1111 / 1346-8138.12496$

130. Igbaseimokumo U, El Shafie S, Al Khal AL. First human infection of Nocardia crassostreae in an immunocompetent patient. Chin Med J. (2016) 129:114-5. doi: 10.4103/0366-6999.172609

131. Inamadar AC, Palit A. Primary cutaneous nocardiosis: a case study and review. Ind J Dermatol Venereol Leprol. (2003) 69:386-91.

132. Ingole KV, Fule RP, Jalgaonkar SV. Primary cutaneous disease due to Nocardia asteriodes-a case report. Ind J Med Sci. (1995) 49:231-2.

133. Ishihara M, Takada D, Sugimoto K, Oguro H, Gonoi T, Akiyama Y, et al. Primary brain abscess caused by Nocardia otitidiscaviarum. Intern Med. (2014) 53:2007-12. doi: 10.2169/internalmedicine.53.1450

134. Jansen C, Frenay HME, Vandertop WP, Visser MR. Intracerebral Nocardia asteroides abscess treated by neurosurgical aspiration and combined therapy with sulfadiazine and cefotaxime. Clin Neurol Neurosurg. (1991) 93:253-5. doi: 10.1016/S0303-8467(05)80015-0
135. Jiang S, Jiang G, Lei TC. Primary cutaneous nocardiosis. J Coll Phys Surg Pakistan. (2014) 24(Suppl 3):S176-7. doi: 10.1001/jama.242.4.333

136. Jiang Y, Huang A, Fang Q. Disseminated nocardiosis caused by Nocardia otitidiscaviarum in an immunocompetent host: a case report and literature review. Exp Therap Med. (2016) 12:3339-46. doi: 10.3892/etm.2016.3755

137. Jimenez-Gallo D, Albarran-Planelles C, Galan-Sanchez F, Linares-Barrios M, Giron- Gonzalez JA. Nocardiosis cutanea primaria por Nocardia farcinica. Rev Clin Espan. (2012) 212:e49-51. doi: 10.1016/j.rce.2012.02.015

138. Johansson B, Fagerholm P, Petranyi G, Claesson Armitage M, Lagali N. Diagnostic and therapeutic challenges in a case of amikacin-resistant Nocardia keratitis. Acta Ophthalmol. (2017) 95:103-5. doi: 10.1111/aos.13182

139. Johnson P, Ammar H. Nocardia brasiliensis vertebral osteomyelitis and epidural abscess. BMJ Case Rep. (2013) 2013:bcr2012008400. doi: 10.1136/bcr-2012-008400

140. Kalavathy CM, Parmar P, Ramalingam MDK, Kaliamurthy J, Jesudasan CAN, Thomas PA. Trimethoprim-sulphamethoxazole therapy in Nocardia keratitis. Clin Exp Ophthal. (2004) 32:424-8. doi: 10.1111/j.1442-9071.2004.00816.x

141. Kamyab A, Fakhoury JDJ, Sutkowski R, Drelichman E, Jacobs MJ. Fulminant colitis secondary to nocardiosis. Int J Color Dis. (2012) 27:841-2. doi: 10.1007/s00384-011-1327-0

142. Kandasamy J, Iqbal HJ, Cooke RPD, Eldridge PR. Primary Nocardia farcinica brain abscess with secondary meningitis and ventriculitis in an immunocompetent patient, successfully treated with moxifloxacin. Acta Neurochir. (2008) 150:505-6. doi: 10.1007/s00701-008-1578-x

143. Kapur N, Adib N, Grimwood K. Nocardia brasiliensis infection mimicking juvenile idiopathic arthritis in a 4-year-old girl. Pediatrics. (2013) 132:e14247. doi: 10.1542/peds.2012-3086

144. Kashyap S, Meel R, Pushker N. Eyelid nocardiosis: an unusual presentation. Ind J Pathol Microbiol. (2010) 53:844-5. doi: 10.4103/0377-4929.72079

145. Kessler R, Follis F, Daube D, Wernly J. Constrictive pericarditis from Nocardia asteroides infection. Annals Thorac Surg. (1991) 52:861-2. doi: 10.1016/0003-4975(91)91228-N

146. Khadka P, Basnet RB, Rijal BP, Sherchand JB. Pulmonary nocardiosis masquerading renascence of tuberculosis in an immunocompetent host: a case report from Nepal. BMC Res Notes. (2018) 11:488. doi: 10.1186/s13104-018-3604-2

147. Khan SNH, Sanche SE, Robinson CA, Pirouzmand F. N. Paucivorans infection presenting as a brain abscess. Canad J Neurol Sci. (2006) 33:426-7. doi: 10.1017/S0317167100005436

148. Kim J, Kang M, Kim J, Jung S, Park J, Lee D, et al. A case of Nocardia farcinica pneumonia and mediastinitis in an immunocompetent patient. Tuberc Respir Dis. (2016) 79:101-3. doi: 10.4046/trd.2016.79.2.101

149. Kim MS, Choi H, Choi KC, Shin BS. Primary cutaneous nocardiosis due to Nocardia vinacea: first case in an immunocompetent patient. Clin Exp Dermatol. (2011) 36:812-4. doi: 10.1111/j.1365-2230.2011.04090.x

150. Kitamura A, Sakurai T, Tomita K, Fujita T, Miki Y, Nakamura T, et al. A case of primary pulmonary nocardiosis with multiple pulmonary nodules successfully treated with moxifloxacin. J Japan Respir Society. (2009) 47:537-42.

151. Kranick SM, Zerbe CS. Case report from the NIH clinical center: CNS nocardiosis. J Neurovirol. (2013) 19:505-7. doi: 10.1007/s13365-013-0193-7

152. Kresch-Tronik NS, Carrillo-Casas EM, Arenas R, Atoche C, Del Rio-Avila C, Ochoa-Carrera LA, et al. (2013). First case of mycetoma associated with Nocardia takedensis. J Dermatol 40:135-6. doi: 10.1111/1346-8138.12009

153. Kresch-Tronik NS, Carrillo-Casas EM, Arenas R, Atoche C, Ochoa-Carrera LA, Xicohtencatl-Cortes J, et al. Nocardia harenae, an uncommon causative organism of mycetoma: report on two patients. J Med Microbiol 61(Pt 8):1153-5. doi: 10.1099/jmm.0.042044-0

154. Kroe DM, Shulman N, Kirsch CM, Wehner JH. An anterior mediastinal mass with draining sternal sinus tracts due to Nocardia braziliensis. West J Med. (1997) 167:47-9.

155. Krone A, Schaal KP, Brawanski A, Schuknecht B. Nocardial cerebral abscess cured with imipenem/amikacin and enucleation. Neurosurg Rev. (1989) 12:333-40.

156. Kumar TS, Xavier Scott J, Viswanathan S, Agarwal I, Mohan Raj P, Lalitha MK. Cervicofacial nocardiosis in an immunocompetent child. Acta Paediatr. (2005) 94:1342-3. doi: 10.1111/j.1651-2227.2005.tb02100.x 
157. Lake EP, Hughart R, Jones ST, Kreppel A, Tsoukas M, Harrington AT. Cutaneous nocardiosis: a conspicuous eyelid eschar. J Pediatr. (2016) 177:327. doi: 10.1016/j.jpeds.2016.06.084

158. Laurin JM, Resnik CS, Wheeler D, Needleman BW. Vertebral osteomyelitis caused by Nocardia asteroides: report and review of the literature. $J$ Rheumatol. (1991) 18:455-8.

159. Lazo Torres AM, Galvez Contreras C, Collado Romacho A, Gamir Ruiz FJ, Yelamos Rodriguez F, Lopez Martinez G. Nocardia endocarditis in a native mitral valve. Rev Espan Cardiol. (2004) 57:787-8. doi: 10.1016/s1885-5857(06)60314-9

160. Lederman ER, Crum NF. A case series and focused review of nocardiosis: clinical and microbiologic aspects. Medicine. (2004) 83:300-13. doi: 10.1097/01.md.0000141100.30871.39

161. Lee TG, Jin WJ, Jeong WS, Moon SH, Kwon TG, Lee SK, et al. Primary cutaneous nocardiosis caused by Nocardia takedensis. Annals Dermatol. (2017) 29:471-5. doi: 10.5021/ad.2017.29.4.471

162. Leitner E, Valentin T, Hoenigl M, Lanz P, Flick H, Zollner-Schwetz I, et al. First report of Nocardia asiatica olecranon bursitis in an immunocompetent traveler returning to Austria. J Clin Microbiol. (2013) 51:2461-2. doi: 10.1128/JCM.00517-13

163. Lewis KE, Ebden P, Wooster SL, Rees J, Harrison GAJ. Multi-system infection with Nocardia farcinica therapy with linezolid and minocycline. J Infect. (2003) 46:199-202. doi: 10.1053/jinf.2002.1122

164. Lin JC, Ward TP, Belyea DA, McEvoy P, Kramer KK. Treatment of Nocardia asteroides keratitis with polyhexamethylene biguanide. Ophthalmology. (1997) 104:1306-11. doi: 10.1016/S0161-6420(97)30143-2

165. Lin Y-C, Huang Z-Y, Sun J-R, Yu C-M, Wang C-H. First case report of Nocardia brasiliensis infection causing necrotizing fasciitis in an immunocompetent patient. J Microbiol Immunol Infect. (2016) 49:824-5. doi: 10.1016/j.jmii.2016.03.007

166. Lohmeyer JA, Machens, H-G, Werber, K-D. A case of severe cutaneous nocardiosis. J H Surg. (2010) 35:72-3. doi: 10.1177/1753193409 344814

167. Lyos AT, Tuchler RE, Malpica A, Spira M. Primary softtissue nocardiosis. Annals Plastic Surg. (1995) 34:212-4. doi: 10.1097/00000637-199502000-00019

168. Magalhaes GM, De Castro Oliveira SC, De Brito Soares AC, Machado-Pinto J, De Resende MA. Mycetoma caused by Nocardia caviae in the first Brazilian patient. Int J Dermatol. (2010) 49:56-8. doi: 10.1111/j.1365-4632.2009.04263.x

169. Maraki S, Chochlidakis S, Nioti E, Tselentis Y. Primary lymphocutaneous nocardiosis in an immunocompetent patient. Annals Clin Microbiol Antimicrob. (2004) 3:24. doi: 10.1186/1476-0711-3-24

170. Maraki S, Scoulica E, Alpantaki K, Dialynas M, Tselentis Y. Lymphocutaneous nocardiosis due to Nocardia brasiliensis. Diagn Microbiol Infect Dis. (2003) 47:341-4. doi: 10.1016/S0732-8893(03)00090-7

171. Maraki S, Scoulica E, Nioti E, Tselentis Y. Nocardial infection in crete, Greece: review of fifteen cases from 2003 to 2007. Scand J Infect Dis. (2009) 41:122-7. doi: 10.1080/00365540802651905

172. Marchandin H, Eden A, Jean-Pierre H, Reynes J, Jumas-Bilak E, Boiron $\mathrm{P}$, et al. Molecular diagnosis of culture-negative cerebral nocardiosis due to Nocardia abscessus. Diagn Microbiol Infect Dis. (2006) 55:237-40. doi: 10.1016/j.diagmicrobio.2006.01.023

173. Marlowe M, Ali-Ahmad D, Cherrick I, Higgins MJ, Kiska DL, Domachowske JB. Central nervous system Nocardiosis in an immunocompetent child. Pediatr Infect Dis J. (2000) 19:661--2. doi: 10.1097/00006454-200007000-00019

174. Martinez RE, Couchel S, Swartz WM, Smith MB. Mycetoma of the hand. J Hand Surg. (1989) 14:909-12. doi: 10.1016/S0363-5023(89)80102-9

175. Masaki T, Masaki T, Miyamoto H, Ohkusu K, Ezaki T. Nocardia elegans infection involving purulent arthritis in humans. J Infect Chemother. (2012) 18:386-9. doi: 10.1007/s10156-011-0311-5

176. Matsuo K, Takeuchi M, Kawata N, Nabe M, Okamoto M, Tada S, et al. Pulmonary Nocardia otitidiscaviarum infection in an immunocompetent host. J Japan Respir Society. (2000) 38:844-9.

177. Mehta RS, Jain D, Chitnis DS. Nocardial abscess of spinal cord [1]. Neurol India. (1999) 47:243-4.
178. Menendez R, Cordero PJ, Santos M, Gobernado M, Marco V. Pulmonary infection with Nocardia species: a report of 10 cases and review. Euro Respir J. (1997) 10:1542-6.

179. Miguel Noriega L, Gonzalez P, Oddo D, Perez J, Frenkel J, Hurtado F, et al. Disseminated nocardiosis in 3 immunocompetent patients. Rev Med Chile. (1995) 123:1263-9.

180. Mirza SH, Campbell C. Mycetoma caused by Nocardia transvalensis. J Clin Pathol. (1994) 47:85-6. doi: 10.1136/jcp.47.1.85

181. Misra AS, Biswas A, Deb P, Dhibar T, Das SK, Roy T. Compressive myelopathy due to nocardiosis from dermal lesion. J Assoc Phys India. (2003) 51:318-21.

182. Mitja O, Hays R, Van Straten C, Robson J, Koka M, Bassat Q. Mycetoma caused by Nocardia yamanashiensis, Papua New Guinea. Am J Trop Med Hygiene. (2012) 86:1043-5. doi: 10.4269/ajtmh.2012.11-0670

183. Mittal V, Fernandes M. Cotrimoxazole-resistant Nocardia sclerokeratitis: effective therapy with fourth-generation fluoroquinolones. Can J Ophthalmol. (2012) 47:e58-60. doi: 10.1016/j.jcjo.2012.07.007

184. Mogilner A, Jallo GI, Zagzag D, Kelly PJ. Nocardia abscess of the choroid plexus: clinical and pathological case report. Neurosurgery. (1998) 43:949-52. doi: 10.1097/00006123-199810000-00130

185. Mongkolrattanothai K, Ramakrishnan S, Zagardo M, Gray B. Ventriculitis and choroid plexitis caused by multidrug-resistant nocardia pseudobrasiliensis. Pediatr Infect Dis J. (2008) 27:666-8. doi: 10.1097/INF.0b013e31816a43bf

186. Montoya J, Carpenter JL, Holmes GP, Hurley DL, Winn R. Disseminated Nocardia transvalensis Infection with osteomyelitis and multiple brain abscesses. Scand J Infect Dis. (2003) 35:189-96. doi: 10.1080/0036554021000026959

187. Morita H, Torii M, Yokoyama T, Ebi M, Takakuwa O, Nakamura A, et al. A case of pulmonary nocardiosis with a polypoid lesion in a bronchus. J Japan Respir Soc. (2004) 42:893-6.

188. Moylett EH, Pacheco SE, Brown-Elliott BA, Perry TR, Buescher ES, Birmingham MC, et al. Clinical experience with linezolid for the treatment of nocardia infection. Clin Infect Dis. (2003) 36:313-8. doi: 10.1086/345907

189. Mu Y-Z, Liu Y, Wang Y-J, Zhang Z-Z. A case report and review of lymphocutaneous nocardiosis caused by Nocardia brasiliensis reported in China. Dermatol Ther. (2019) 32:e13001. doi: 10.1111/dth.13001

190. Mufti P, Jamil B. Pneumonia caused by Nocardia caviae in a healthy neonate. J Pak Med Assoc. (1995) 45:272-3.

191. Mukunda BN, Shekar R, Bass S. Solitary spinal intramedullary abscess caused by Nocardia asteroides. South Med J. (1999) 92:1223-4. doi: 10.1097/00007611-199912000-00020

192. Munoz-Hernandez B, Noyola MC, Palma-Cortes G, Rosete DP, Galvan MA, Manjarrez ME. Actinomycetoma in Arm disseminated to lung with grains of Nocardia brasiliensis with peripheral filaments. Mycopathologia. (2009) 168:37-40. doi: 10.1007/s11046-009-9189-5

193. Naguib MT, Fine DP. Brain abscess due to Nocardia brasiliensis hematogenously spread from a pulmonary infection. Clin Infect Dis. (1995) 21:459-60. doi: 10.1093/clinids/21.2.459

194. Naha K, Dasari S, Vivek G, Prabhu M. Primary abdominal Nocardiosis masquerading as tubercular pelvic inflammatory disease in an immunocompetent individual. BMJ Case Rep. (2013) 2013:bcr2012008076. doi: 10.1136/bcr-2012-008076

195. Naka W, Miyakawa S, Niizeki H, Fukuda T, Mikami Y, Nishikawa T. Unusually located lymphocutaneous nocardiosis caused by Nocardia brasiliensis. Br J Dermatol. (1995) 132:609-13. doi: 10.1111/j.1365-2133.1995.tb08719.x

196. Nakahara Y, Nakahara Y, Ikegami Y, Ishida T, Ushida S, Mochizuki Y, et al. A case of pulmonary nocardiosis diagnosed by percutaneous aspiration. Japan J Thoracic Dis. (1990) 28:651-5. doi: 10.11389/jjrs1963.28.651

197. Nalini A, Saini J, Mahadevan A. Central nervous system norcardiosis with granulomatous pachymeningitis and osteomyelitis of skull vault. Ind J Pathol Microbiol. (2014) 57:332-4. doi: 10.4103/0377-4929.134735

198. Navarrete-Navarrete N, Escobar Sevilla J, Toribio Garcia M, Urbano F, Sabio JM, Jimenez-Alonso J. A man with unilateral endophthalmitis: a case of disseminated nocardiosis. Case Rep Infect Dis. (2015) 2015:607421. doi: $10.1155 / 2015 / 607421$ 
199. Nguyen NM, Sink JR, Carter AJ, Asrani F. Nocardiosis incognito: primary cutaneous nocardiosis with extension to myositis and pleural infection. JAAD Case Rep. (2017) 4:33-5. doi: 10.1016/j.jdcr.2017.08.010

200. Numata S, Numata T, Gonoi T, Matsunaga K. Successful treatment of primary cutaneous Nocardia brasiliensis infection with oral potassium iodide. J Dermatol. (2016) 43:843-4. doi: 10.1111/1346-8138.13293

201. Oda R, Sekikawa Y, Hongo I. Primary cutaneous nocardiosis in an immunocompetent patient. Intern Med. (2017) 56:469-70. doi: 10.2169/internalmedicine.56.7810

202. Ogasawara Y, Takita Y, Hiruma M, Mikami Y, Muto M. Primary cutaneous nocardiosis due to Nocardia brasiliensis in an immunocompetent patient. $J$ Dermatol. (2005) 32:230-2. doi: 10.1111/j.1346-8138.2005.tb00754.x

203. Oshiro S, Ohnishi $H$, Ohta $M$, Tsuchimochi $H$. Intraventricular rupture of nocardia brain abscess. Neurol Med. (2003) 43:360-3. doi: 10.2176/nmc.43.360

204. Ozgenc O, Avci M, Ari A, Celebi IY, Coşkuner SA. Long-term treatment of persistent disseminated Nocardia cyriacigeorgica infection. Brazil J Infect Dis. (2014) 18:556-60. doi: 10.1016/j.bjid.2014.03.007

205. Pai S, Pai K, Sharma S. Cutaneous nocardiosis: an underdiagnosed pathogenic infection. BMJ Case Rep. (2015) 2015:bcr2014208713. doi: 10.1136/bcr-2014-208713

206. Palmieri JR, Santo A, Johnson SE. Soil-acquired cutaneous nocardiosis on the forearm of a healthy male contracted in a swamp in rural eastern Virginia. Int Med Case Rep J. (2014) 7:41-7. doi: 10.2147/IMCRJ.S59315

207. Pandya VB, Petsoglou C. Nocardia transvalensis resistant to amikacin: an unusual cause of microbial keratitis. Cornea. (2008) 27:1082-5. doi: 10.1097/ICO.0b013e3181783a20

208. Papaventsis D, Siafakas N, Kondyli L, Akritidou M, Pantazi P, Perdikari E, et al. Nocardia puris endophthalmitis. Ind J Med Microbiol. (2009) 27:168-70. doi: 10.4103/0255-0857.49438

209. Paredes BE, Hunger RE, Braathen LR, Brand CU. Cutaneous nocardiosis caused by Nocardia brasiliensis after an insect bite. Dermatology. (1999) 198:159-61. doi: 10.1159/000018094

210. Patel R, Sise A, Al-Mohtaseb Z, Garcia N, Aziz H, Amescua G, et al. Nocardia asteroides keratitis resistant to amikacin. Cornea. (2015) 34:1617-9. doi: 10.1097/ICO.0000000000000634

211. Patil A, Cherian A, Iype T, Sandeep P. Nocardial brain abscess in an immunocompetent individual. Neurol India. (2011) 59:779-82. doi: $10.4103 / 0028-3886.86571$

212. Patil SP, Gautam MM, Sodha AA, Khan KJ. Primary cutaneous nocardiosis with craniocerebral extension: a case report. Dermatol Online J. (2009) 15:8.

213. Philit F, Boibieux A, Coppere B, Reverdy ME, Peyramond D, et al. Nocardia asteroides meningitis without brain abscess in an non-immunodepressed adult. Presse Med. (1994) 23:346.

214. Pintado V, Gomez-Mampaso E, Meseguer MA, Gonzalez-Palacios F, Yturriaga R. Systemic nocardiosis of fatal outcome in a previously health girl. Enferm Infecc Microbiol Clin. (2000) 18:485-6.

215. Poland GA, Jorgensen CR, Sarosi GA. Nocardia asteroides pericarditis: report of a case and review of the literature. Mayo Clin Proc. (1990) 65:819-24. doi: 10.1016/S0025-6196(12)62573-7

216. Provost F, Laurent F, Uzcategui LR, Boiron P. Molecular study of persistence of Nocardia asteroides and Nocardia otitidiscaviarum strains in patients with long-term nocardiosis. J Clin Microbiol. (1997) 35:1157-60.

217. Pyatigorskaya N, Brugieres P, Hodel J, Mekontso Dessap A, Gaston A. What is your diagnosis? J Neuroradiol. (2010) 37:192-5. doi: 10.1016/j.neurad.2009.07.007

218. Rafiei N, Peri AM, Righi E, Harris P, Paterson DL. Central nervous system nocardiosis in Queensland: a report of 20 cases and review of the literature. Med. (2016) 95:e5255. doi: 10.1097/MD.0000000000005255

219. Rajendran C, Kandhari S. Mycetoma due to nocardia brasiliensis: first case report from the union territory of Delhi: Nocavdia brasiliensismyzetom: erster fallbericht aus der Delhi-Union. Mycoses. (1989) 32:476-81. doi: 10.1111/j.1439-0507.1989.tb02286.x

220. Ramamoorthi K, Pruthvi BC, Rao NR, Belle J, Chawla K. Pulmonary nocardiosis due to Nocardia otitidiscaviarum in an immunocompetent host- a rare case report. Asian Pac J Trop Med. (2011) 4:414-6. doi: 10.1016/S1995-7645(11)60116-8
221. Raszka D, Popelka S Jr, Hert J, Jahoda D, Landor I, Vavrik P. Rare case of osteomyelitis of tibial shaft caused by Nocardia cyriacigeorgica. Folia Microbiol. (2018) 63:525-32. doi: 10.1007/s12223-018-0589-0

222. Ravage ZB, Singerman LJ. Endogenous Nocardial chorioretinitis in an immunocompetent patient. Ret Cases Brief Rep. (2009) 3:27-30. doi: 10.1097/ICB.0b013e31814fae6f

223. Richards ADM, Stewart C, Karthik H, Lake SR. Bilateral subretinal abscesses: the first case of disseminated Nocardia beijingensis in Australia. Clin Exp Ophthal. (2015) 43:843-5. doi: 10.1111/ceo.12575

224. Roca B, Merino J. Nocardia brain abscess. Int J Infect Dis. (2010) 3:e383-4. doi: 10.1016/j.ijid.2009.07.015

225. Rodriguez-Lozano J, Arminanzas Castillo C, Ruiz de Alegria Puig C, Ventosa Ayarza JA, Farinas MC, Aguero J, et al. Post-traumatic endophthalmitis caused by Nocardia nova. JMM Case Rep. (2019) 6:e005175. doi: 10.1099/jmmcr.0.005175

226. Roquer J, Pou A, Herraiz J, Campodarve I, Sequeira T, Vilato J, et al. Primary cerebral abscess due to nocardia presenting as "ghost tumor": clinical and pathological study. Euro Neurol. (1990) 30:254-7. doi: 10.1159/000117357

227. Rosendale DE, Myers C, Boyko EJ, Jafek B. Nocardia asteroides cervical osteomyelitis in an immunocompetent host. Otolaryngology. (1988) 99:3347. doi: $10.1177 / 019459988809900313$

228. Roubille F, Maxant G, Serre I, Colson P, Battistella P, Calvet B, et al.-L. Fatal systemic nocardia infection revealed by cardiac tamponade. Intern Med. (2010) 49:135-7. doi: 10.2169/internalmedicine.49.2478

229. Rush RB. Contact lens-associated nocardial necrotizing scleritis. Korean $J$ Ophthal. (2013) 27:291-3. doi: 10.3341/kjo.2013.27.4.291

230. Saarinen KA, Lestringant GG, Czechowski J, Frossard PM. Cutaneous nocardiosis of the chest wall and pleura - 10-Year consequences of a hand actinomycetoma. Dermatology. (2001) 202:131-3. doi: 10.1159/000051613

231. Sachs MK. Lymphocutaneous Nocardia brasiliensis infection acquired from a cat scratch: case report and review. Clin Infect Dis. (1992) 15:710-1. doi: 10.1093/clind/15.4.710

232. Salvo Gonzalo S, Grijalba Uche M, Mazon Ramos A, Vila Mendiburu I. Acute otitis media caused by Nocardia asteroides. Acta Otorrinolaringol Espanola. (1996) 47:314-6.

233. Saoji VA, Saoji, V S, Gadegone RW, Menghani PR. Primary cutaneous nocardiosis. Ind J Dermatol. (2012) 57:404-6. doi: 10.4103/0019-5154. 100502

234. Saraca GD, Towersey L, Hay RJ, Londero AT, Martins EC, Amora AT, et al. Mycetoma by Nocardia asteroides: a 9 year follow-up. Rev Instit Med Trop Sao Paulo. (1993) 35:199-204. doi: 10.1590/S0036-46651993000200013

235. Schiaroli E, Pasticci MB, de Carolis E, Mello E, Pallotto C, Leli C, et al. Diagnosis of Nocardia paucivorans central nervous system infection by DNA sequencing from paraffin-embedded tissue. Infezioni Med. (2016) 24:147-52.

236. Schiff TA, Goldman R, Sanchez M, McNeil MM, Brown JM, Klirsfeld D, et al. Primary lymphocutaneous nocardiosis caused by an unusual species of Nocardia: Nocardia transvalensis. J Am Acad Dermatol. (1993) 28:336-40. doi: 10.1016/0190-9622(93)70049-Y

237. Schiff TA, McNeil MM, Brown JM. Cutaneous Nocardia farcinica infection in a nonimmunocompromised patient: case report and review. Clin Infect Dis. (1993) 16:756-60. doi: 10.1093/clind/16.6.756

238. Schwartz JG, McGough DA, Thorner RE, Fetchick RJ, Tio FO, Rinaldi MG. Primary lymphocutaneous Nocardia brasiliensis infection: three case reports and a review of the literature. Diagn Microbiol Infect Dis. (1988) 10:113-20. doi: 10.1016/0732-8893(88)90049-1

239. Schwartz JG, Tio FO. Nocardial osteomyelitis: A case report and review of the literature. Diagn Microbiol Infect Dis. (1987) 8:37-46. doi: 10.1016/0732-8893(87)90045-9

240. Secchin P, Trope BM, Fernandes LA, Barreiros G, Ramos-E-Silva M. Cutaneous Nocardiosis simulating cutaneous lymphatic sporotrichosis. Case Rep Dermatol. (2017) 9:119-29. doi: 10.1159/000471788

241. Seddon M, Ellis-Pegler RB. Lymphocutaneous Nocardia brasiliensis infection: a case report and review. N Zeal Med J. (1995) 108:385-6.

242. Senard O, Blanot S, Jouvion G, Rodriguez-Nava V, Lortholary O, JoinLambert $\mathrm{O}$, et al. Fulminant nocardiosis due to a multidrug-resistant isolate in a 12- year-old immunocompetent child. Pediatrics. (2018) 141:e20163131. doi: 10.1542/peds.2016-3131 
243. Shachor-Meyouhas Y, Ravid S, Suhair H, Kassis I. Primary cutaneous Nocardia brasiliensis cellulitis in immunocompetent child. Harefuah. (2012) 151:476-8.

244. Shah P, Zhu D, Culbertson WW. Therapeutic femtosecond laser-assisted lamellar keratectomy for multidrug-resistant nocardia keratitis. Cornea. (2017) 36:1429-31. doi: 10.1097/ICO.0000000000001318

245. Shanbhag NU, Karandikar S, Deshmukkh PA. Disseminated orbital actinomycetoma: a case report. Ind J Ophthal. (2010) 58:60-3. doi: 10.4103/0301-4738.58474

246. Sharma N, Mahajan V, Agarwal S, Katoch V, Das R, Kashyap M, et al. Nocardial mycetoma: diverse clinical presentations. Ind J Dermatol Venereol Leprol. (2008) 74:635-40. doi: 10.4103/0378-6323.45110

247. Sheffer S, Shreberk-Hassidim R, Olshtain K, Maly A, Zlotogorski A, Ramot Y. Lymphocutaneous nocardiosis caused by Nocardia brasiliensis in an immunocompetent elderly woman. Int J Dermatol. (2016) 55:e45-7. doi: $10.1111 /$ ijd. 12988

248. Shetty VP, Kannappan O, Sarma YS. Salivary gland nocardiosis in an immunocompetent patient. Asian J Surg. (2011) 34:99-101. doi: 10.1016/S1015-9584(11)60028-6

249. Shifren JD, Milliken RG. An acute Nocardia brasiliensis infection of the hand: a case report. J Hand Surg. (1996) 21:309-10. doi: 10.1016/S0363-5023(96)80128-6

250. Shimizu A, Ishikawa O, Nagai Y, Mikami Y, Nishimura K. Primary cutaneous nocardiosis due to Nocardia nova in a healthy woman. Br J Dermatol. (2001) 145:154-6. doi: 10.1046/j.1365-2133.2001.04302.x

251. Shishido H, Deguchi K, Miyake S, Akagawa S, Yoshizawa Y. Multiple drugresistant Nocardia asteroides isolated from a patient with pulmonary nocardiosis. Respir Med. (1998) 92:873-5. doi: 10.1016/S0954-6111(98)90391-2

252. Shivaprakash MR, Rao P, Mandal J, Biswal M, Gupta S, Ray P, et al. Nocardiosis in a tertiary care hospital in North India and review of patients reported from India. Mycopathologia. (2007) 163:267-74. doi: 10.1007/s11046-007-9011-1

253. Sikimić S, Nonković Z, Cvetković D. Recurrent abscessing pneumonia caused by Nocardia. Vojnosanitetski Pregled. Military-Med Pharmac Rev. (1998) 55:559-63.

254. Singh AK, Shukla A, Bajwa R, Agrawal R, Srivastwa N. Pulmonary nocardiosis: unusual presentation in intensive care unit. Ind J Crit Care Med. (2018) 22:125-7. doi: 10.4103/ijccm.IJCCM_472_17

255. Singh S, Verma Y, Pandey P, Singh UB. Granulomatous hepatitis by Nocardia species: an unusual case. Int J Infect Dis. (2019) 81:97-9. doi: 10.1016/j.ijid.2019.01.046

256. Smit LHM, Leemans R, Overbeek BP. Nocardia farcinica as the causative agent in a primary psoas abscess in a previously healthy cattle inspector. Clin Microbiol Infect. (2003) 9:445-8. doi: 10.1046/j.1469-0691.2003.00576.x

257. Soares D, Reis-Melo A, Ferraz C, Guedes Vaz L. Nocardia lung abscess in an immunocompetent adolescent. BMJ Case Rep. (2019) 12. doi: 10.1136/bcr-2018-227499

258. Solano-Varela DM, Barrios-Vidales EM, Plaza DF, Riveros WM, Guzman J, Chica CE, et al. Immunocompetent patient with a brain abscess caused by Nocardia beijingensis in Latin America: a case report. Medicine. (2019) 98:e14879. doi: 10.1097/MD.0000000000014879

259. Sorichetti B, Westerberg BD, Tan R, Kozak FK. Nocardia asteroides sinusitis in a pediatric patient: case report with 20 year follow-up and review of the literature. Int J Pediatr Otorhinol. (2015) 79:1152-4. doi: 10.1016/j.ijporl.2015.04.022

260. Soto-Mendoza N, Bonifaz A. Head actinomycetoma with a double aetiology, caused by Nocardia brasiliensis and N. asteroides. Br J Dermatol. (2000) 143:192-4. doi: 10.1046/j.1365-2133.2000.03615.x

261. Sousa JMP, Wachholz PA, Sette CS, Marques GF, Barreto JA. Mycetoma caused by Nocardia brasiliensis in an immunocompetent patient. J Deutsc Dermatol Gesellsc. (2014) 12:903-5. doi: 10.1111/ddg.12331

262. Sridhar MS, Cohen EJ, Rapuano CJ, Lister MA, Laibson PR. Nocardia asteroides sclerokeratitis in a contact lens wearer. CLAO J. (2002) 28:66-8.

263. Sridhar MS, Sharma S, Garg P, Rao GN. Treatment and outcome of Nocardia keratitis. Cornea. (2001) 20:458-62. doi: 10.1097/00003226-200107000-00003
264. Stanley MW, Deike M, Knoedler J, Iber C. Pulmonary mycetomas in immunocompetent patients: diagnosis by fine-needle aspiration. Diagn Cytopathol. (1992) 8:577-9. doi: 10.1002/dc.2840080607

265. Steinmetz G, Panas K, Puffinbarger W. An acute nocardia infection in a pediatric hand. J Hand Surg. (2019) 44:343.e3. doi: 10.1016/j.jhsa.2018.03.039

266. Suzuki C, Kimura T, Arai A, Maeda T, Tomiyama M, Kannari K, et al. A case of brain nocardiosis successfully treated with minocycline. Brain Nerve. (2006) 58:505-8.

267. Takayanagi K, Kimura Y, Kawakami K, Koyama K, Harada Y, Yamaryo T. A case of pulmonary nocardiosis with Nocardia beijingensis. J Japan Assoc Infect Dis. (2008) 82:43-6. doi: 10.11150/kansenshogakuzasshi1970.82.43

268. Taneja J, Sen B, Danc N. Pulmonary nocardiosis mimicking malignancy. Ind J Med Microbiol. (2015) 34:117-8. doi: 10.4103/0255-0857.167680

269. Tantracheewathorn T, Lolekha S, Tantracheewathorn S. Nocardia pneumonia with empyema thoracis in a healthy neonate: a case report. J Med Assoc Thailand. (2004) 87:438-41.

270. Tellez I, Franco-Paredes C. A woman with chronic subcutaneous swelling of the right foot associated with sinus tracts discharging yellow grains. PLoS Neglect Trop Dis. (2010) 4:e772. doi: 10.1371/journal.pntd.0000772

271. Tenorio-Abreu A, Iglesias-Martin J, Breval IZY, Delgado-Garcia C. Keratitis by Nocardia farcinica in an immunocompetent patient. Description of the first case in Spain. Rev Espan Quimioter. (2017) 30:385-7.

272. Thoms, K-M, Zimmermann O, Schupp P, Thoms S, Emmert S. Nocardia otitidiscaviarum: cause of long-term cutaneous abscesses on the leg of an immunocompetent man. Arch Dermatol. (2007) 143:1073-87. doi: 10.1001/archderm.143.8.1086

273. Tilak R, Agarwal D, Lahiri TK, Tilak V. Pulmonary nocardiosis presenting as fungal ball-a rare entity. J Infect Dev Countries. (2008) 2:143-5. doi: 10.3855/T2.2.143

274. Townell N, Locke T, Gibbons M, Murphy D, Francis J, Nourse C. Mycetoma in Timor-Leste and first report of nocardiosis. Infect Dis Rep. (2018) 10:7804. doi: 10.4081/idr.2018.7804

275. Trichet E, Cohen-Bacrie S, Conrath J, Drancourt M, Hoffart L. Nocardia transvalensis keratitis: an emerging pathology among travelers returning from Asia. BMC Infect Dis. (2011) 11:296. doi: 10.1186/1471-2334-11-296

276. Tseng SH, Chen JJ, Hu FR. Nocardia brasiliensis keratitis successfully treated with therapeutic lamellar keratectomy. Cornea. (1996) 15:165-7. doi: 10.1097/00003226-199603000-00009

277. Tsushima K, Koizumi T, Aoki H, Furuta K, Fujimoto K, Kubo K. A case of acute respiratory distress syndrome caused by systemic nocardiosis. Respiration. (2000) 67:591-2. doi: 10.1159/000029580

278. Valarezo J, Cohen J, Valarezo L, Spektor S, Shoshan Y, Rosenthal G, et al. Nocardial cerebral abscess: report of three cases and review of the current neurosurgical management. Neurol Res. (2003) 25:27-30. doi: $10.1179 / 016164103101201076$

279. Valbuena Alvarez R, Cajide Montero J, Ortiz Cabria R, Santos-Ascarza Tabares L, Rodriguez de la Rua Roman J, de la Rosa Kehrmann M, et al. Acute systemic nocardiosis. Renal abscess. Arch Espan Urol. (1996) 49:529-31.

280. Vanegas S, Franco-Cendejas R, Cicero A, Lopez-Jacome E, Colin C, Hernandez M. Nocardia brasiliensis-associated femorotibial osteomyelitis. Int J Infect Dis. (2014) 20:63-5. doi: 10.1016/j.ijid.2013. 11.002

281. Varghese GK, Ramani R, Bhat KR, Shivananda PG. Nocardia brasiliensis meningitis. Postgr Med J. (1992) 68:986. doi: 10.1136/pgmj.68.806.986

282. Vongphoumy I, Dance DAB, Dittrich S, Logan J, Davong V, Rattanavong S, et al. Case report: actinomycetoma caused by Nocardia aobensis from Lao PDR with favourable outcome after short-term antibiotic treatment. PLoS Negl Trop Dis. (2015) 9:e0003729. doi: 10.1371/journal.pntd.0003729

283. Wada A, Matsuda S, Kubota H, Miura H, Iwamoto Y. Primary lymphocutaneous nocardiosis caused by Nocardia otitidiscaviarum. Hand Surg. (2002) 07:285-7. doi: 10.1142/S021881040200114X

284. Wang A, Xu Q, Wang Y, Liao H. Orbital and intracranial Nocardia farcinica infection caused by trauma to the orbit: a case report. BMC Infect Dis. (2019) 19:953. doi: 10.1186/s12879-019-4605-z

285. Wang R, Yao X, Li R. Mycetoma in China: a case report and review of the literature. Mycopathologia. (2019) 184:327-34. doi: 10.1007/s11046-019-00324-z 
286. Wang X, Zhou T, Deng D, Guo Y. A case of cutaneous nocardiosis with involvement of the trachea, anterior mediastinum and sternum. Case Rep Dermatol. (2010) 2:177-82. doi: 10.1159/000321635

287. Wegerle S, Markus A, Weber N, Steffen H, King B, Eder W, et al. Pulmonary nocardiosis with trimethoprime/sulphamethoxazole-resistant Nocardia paucivorans in a patient with no signs of immunosuppression. Pneumologie. (2007) 61:46-51. doi: 10.1055/s-2006-944276

288. Welsh O, Salinas-Carmona MC, Brown-Elliott BA, Smith T, Cardenas-De La Garza JA, Wallace RJ Jr. Disseminated actinomycetoma due to Nocardia wallacei. Int J Dermatol. (2018) 57:580-2. doi: 10.1111/ijd.13909

289. Williams PJ, Robinson J, Hubbard GB. Bleb-associated exogenous nocardia endophthalmitis. JAMA Ophthal. (2017) 135:e17427. doi: 10.1001/jamaophthalmol.2017.4276

290. Wongthim S, Charoenlap P, Udompanich V, Punthumchinda K, Suwanagool P. Pulmonary nocardiosis in Chulalongkorn Hospital. J Med Assoc Thailand. (1991) 74:271-7.

291. Wortman PD. Treatment of a Nocardia brasiliensis mycetoma with sulfamethoxazole and trimethoprim, amikacin, and amoxicillin and clavulanate. Arch Dermatol. (1993) 129:564-7. doi: 10.1001/archderm.1993.01680260032002

292. Yaşar Z, Acat M, Onaran H, Ozgul MA, Fener N, Talay F, et al. An unusual case of pulmonary nocardiosis in immunocompetent patient. Case Rep Pulmonol. (2014) 2014:963482. doi: 10.1155/2014/963482

293. Yildiz O, Alp E, Tokgoz B, Tucer B, Aygen B, Sumerkan B, et al. Nocardiosis in a teaching hospital in the Central Anatolia region of Turkey: treatment and outcome. Clin Microbiol Infect. (2005) 11:495-9. doi: 10.1111/j.1469-0691.2005.01145.x

294. Z'Graggen WJ, Bregenzer T, Fankhauser H, Arnoux A, Laeng H, Itin PH. Primary cutaneous nocardiosis in an immune-competent patient. Euro $J$ Dermatol. (2001) 11:569-71.

295. Zhuang K, Tang J, Ran Y. Image gallery: acute primary cutaneous nocardiosis due to Nocardia brasiliensis. Br J Dermatol. (2017) 176:e97. doi: 10.1111/bjd.15394

296. Zufferey P, Wenger A, Bille J, Hofstetter JR. Disseminated nocardiosis due to Nocardia brasiliensis in an ambulatory patient. Revue Suisse Med Praxis. (1989) 78:718-21.

297. Zúñiga M, Hunziker MF, Nico MM, Rivitti EA, Festa-Neto C. Actinomycetoma of the scalp due to Nocardia brasiliensis: case report and review of the literature. Int J Dermatol. (2015) 54:695-8. doi: 10.1111/ijd.12107

298. Mufti P, Jamil B. Pneumonia caused by nocardia caviae in a healthy neonate. J Pak Med Assoc. (1995) 45:272-3.

299. Hernandez-Hernandez F, Lopez-Martinez R, Mendez-Tovar LJ, Manzano-Gayosso P. Nocardia brasiliensis: in vitro and in vivo growth response to steroid sex hormones. Mycopathologia. (1995) 132:79-85. doi: 10.1007/BF01103779

300. Lovett IS, Houang ET, Burge S, Turner-Warwick M, Thompson FD, Harrison AR, et al. An outbreak of Nocardia asteroides infection in a renal transplant unit. Q J Med. (1981) 50:123-35. doi: 10.1093/oxfordjournals.qjmed.a067675

301. Houang ET, Lovett IS, Thompson FD, Harrison AR, Joekes AM, Goodfellow M. Nocardia asteroides infection-a transmissible disease. J Hosp Infect. (1980) 1:31-40. doi: 10.1016/0195-6701(80)90029-8

302. Sahathevan M, Harvey FA, Forbes G, O'Grady J, Gimson A, Bragman S, et al. Epidemiology, bacteriology and control of an outbreak of Nocardia asteroides infection on a liver unit. J Hosp Infect. (1991) 18(Suppl. A):473-80. doi: 10.1016/0195-6701(91)90059-H

303. Exmelin L, Malbruny B, Vergnaud M, Prosvost F, Boiron P, Morel C. Molecular study of nosocomial nocardiosis outbreak involving heart transplant recipients. J Clin Microbiol. (1996) 34:1014-6. doi: 10.1128/JCM.34.4.1014-1016.1996

304. Blumel J, Blumel E, Yassin AF, Schmidt-Rotte H, Schaal KP. Typing of Nocardia farcinica by pulsed-field gel electrophoresis reveals an endemic strain as source of hospital infections. J Clin Microbiol. (1998) 36:118-22. doi: 10.1128/JCM.36.1.118-122.1998

305. Kachi S, Okazaki M, Takeda H, Igarashi H, Kobayashi O, Watanabe H, et al. Outbreak of Nocardia farcinica infection with the same pattern in randomly amplified polymorphic DNA analysis. J Hosp Infect. (2006) 62:502-6. doi: 10.1016/j.jhin.2005.02.004
306. Apostolou A, Bolcen SJ, Dave V, Jani N, Lasker BA, Tan CG, et al. Nocardia cyriacigeorgica infections attributable to unlicensed cosmetic proceduresan emerging public health problem? Clin Infect Dis. (2012) 55:251-3. doi: $10.1093 / \mathrm{cid} / \mathrm{cis} 341$

307. Chen J, Zhou H, Xu P, Zhang P, Ma S, Zhou J. Clinical and radiographic characteristics of pulmonary nocardiosis: clues to earlier diagnosis. PLoS ONE. (2014) 9:e90724. doi: 10.1371/journal.pone.0090724

308. Wilson JW. Nocardiosis: updates and clinical overview. Mayo Clin Proc. (2012) 87:403-7. doi: 10.1016/j.mayocp.2011.11.016

309. McNeil MM, Brown JM. The medically important aerobic actinomycetes: epidemiology and microbiology. Clin Microbiol Rev. (1994) 7:357-417. doi: 10.1128/CMR.7.3.357

310. Steinbrink J, Leavens J, Kauffman CA, Miceli MH. Manifestations and outcomes of nocardia infections: comparison of immunocompromised and nonimmunocompromised adult patients. Medicine. (2018) 97:e12436. doi: 10.1097/MD.0000000000012436

311. Stropnik Z. Isolation of Nocardia asteroides from human skin. Sabouraudia. (1965) 4:41-4. doi: 10.1080/00362176685190111

312. Rosett W, Hodges GR. Recent experiences with nocardial infections. Am J Med Sci. (1978) 276:279-85. doi: 10.1097/00000441-19781100000004

313. Ishikawa O. Aerobic gram-positive pleomorphic rods isolated from dental plaque and gingival crevice. Bull Tokyo Med Dent Univ. (1980) 27:71-7.

314. Yildiz O, Doganay M. Actinomycoses and Nocardia pulmonary infections. Curr Opin Pulm Med. (2006) 12:228-34. doi: 10.1097/01.mcp.0000219273.57933.48

315. Conville PS, Brown-Elliott BA, Smith T, Zelazny AM. The complexities of nocardia taxonomy and identification. J Clin Microbiol. (2017) 56:e01419-17. doi: 10.1128/JCM.01419-17

316. Brown-Elliott BA, Brown JM, Conville PS, Wallace RJ Jr. Clinical and laboratory features of the Nocardia spp. based on current molecular taxonomy. Clin Microbiol Rev. (2006) 19:259-82. doi: 10.1128/CMR.19.2.259-282.2006

317. Sugar AM, Schoolnik GK, Stevens DA. Antibody response in human nocardiosis: identification of two immunodominant culture-filtrate antigens derived from Nocardia asteroides. J Infect Dis. (1985) 151:895-901. doi: 10.1093/infdis/151.5.895

318. Vera-Cabrera L, Salinas-Carmona MC, Welsh O, Rodriguez MA. Isolation and purification of two immunodominant antigens from Nocardia brasiliensis. J Clin Microbiol. (1992) 30:1183-8. doi: 10.1128/JCM.30.5.1183-1188.1992

319. Salinas-Carmona MC, Vera L, Welsh O, Rodriguez M. Antibody response to Nocardia brasiliensis antigens in man. Zentralbl Bakteriol. (1992) 276:390-7. doi: 10.1016/S0934-8840(11)80546-3

320. Angeles AM, Sugar AM. Identification of a common immunodominant protein in culture filtrates of three Nocardia species and use in etiologic diagnosis of mycetoma. J Clin Microbiol. (1987) 25:2278-80. doi: 10.1128/JCM.25.12.2278-2280.1987

321. Boiron P, Provost F. Use of partially purified 54-kilodalton antigen for diagnosis of nocardiosis by Western blot (immunoblot) assay. J Clin Microbiol. (1990) 28:328-31. doi: 10.1128/JCM.28.2.328-331.1990

322. Saubolle MA, Sussland D. Nocardiosis: review of clinical and laboratory experience. J Clin Microbiol. (2003) 41:4497-501. doi: 10.1128/JCM.41.10.4497-4501.2003

323. Wauters G, Avesani V, Charlier J, Janssens M, Vaneechoutte M, Delmée M. Distribution of nocardia species in clinical samples and their routine rapid identification in the laboratory. J Clin Microbiol. (2005) 43:2624-8. doi: 10.1128/JCM.43.6.2624-2628.2005

324. Law BJ, Marks MI. Pediatric nocardiosis. Pediatrics. (1982) 70:560-5.

325. Kandi V. Human nocardia infections: a review of pulmonary nocardiosis. Cureus. (2015) 7:e304. doi: 10.7759/cureus.304

326. Budzik JM, Hosseini M, Mackinnon AC Jr, Taxy JB. Disseminated Nocardia farcinica: literature review and fatal outcome in an immunocompetent patient. Surg Infect. (2012) 13:163-70. doi: 10.1089/sur.2011.012

327. Musgrave WE, Clegg MT. The etiology of mycetoma. Phillippine J Sc. (1907) B:477-511.

328. Steele AE, Lee RI. A case of infection with Nocardia. Bost M S J. (1913) 169:502-3. doi: 10.1056/NEJM191310021691404 
329. de Korté WE. Nocardia cylindracea: a South African otomycosis. Ann Trop Med. (1917) 11:265-78. doi: 10.1080/00034983.1918.11684139

330. Alestra L, Girolami M. Endocarditi da nocardie. Policlin Med. (1937) 44:441.

331. Lyons C, Owen CR, Ayers WB. Sulfonamide therapy in actinomycotic infections. Surgery. (1943) 14:99.

332. Cook F V, Farrar WE Jr. Treatment of Nocardia asteroides infection with trimethoprim-sulfamethoxazole. South Med J. (1978) 71:512-5. doi: 10.1097/00007611-197805000-00011

333. Wallace RJJ, Septimus EJ, Williams TWJ, Conklin RH, Satterwhite TK, Bushby MB, et al. Use of trimethoprim-sulfamethoxazole for treatment of infections due to Nocardia. Rev Infect Dis. (1982) 4:315-25. doi: 10.1093/clinids/4.2.315

334. Scopetti F, Iona E, Fattorini L, Goglio A, Franceschini N, Amicosante $\mathrm{G}$, et al. Activity of antimicrobial drugs evaluated by agar dilution and radiometric methods against strains of Nocardia asteroides isolated in Italy from immunocompromised patients. J Chemother. (1994) 6:29-34. doi: 10.1080/1120009X.1994.11741125

335. Husain S, McCurry K, Dauber J, Singh N, Kusne S. Nocardia infection in lung transplant recipients. J Hear Lung Transplant. (2002) 21:354-9. doi: 10.1016/S1053-2498(01)00394-1

336. Muñoz J, Mirelis B, Aragón LM, Gutiérrez N, Sánchez F, Español M, et al. Clinical and microbiological features of nocardiosis 1997-2003. J Med Microbiol. (2007) 56:545-50. doi: 10.1099/jmm.0.46774-0

337. Southern PM Jr, Kutscher AE, Ragsdale R, Luttrell B. Susceptibility in vitro of Nocardia species to antimicrobial agents. Diagn Microbiol Infect Dis. (1987) 8:119-22. doi: 10.1016/0732-8893(87)90159-3

338. Nguyen AT, Gentry CA, Furrh RZ. A comparison of adverse drug reactions between high- and standard-dose trimethoprimsulfamethoxazole in the ambulatory setting. Curr Drug Saf. (2013) 8:114-9. doi: 10.2174/1574886311308020004

339. Welsh O, Vera-Cabrera L, Salinas-Carmona MC. Current treatment for nocardia infections. Expert Opin Pharmacother. (2013) 14:2387-98. doi: 10.1517/14656566.2013.842553

340. Caron F, Meurice JC, Dore P, Perault MC, Breux JP, Patte F. Gingival hyperplasia: a new side effect associated with trimethoprimsulfamethoxazole (TML-SMX) treatment in pulmonary nocardiosis. Therapie. (1997) 52:73-4.

341. Bartels RH, van der Spek JA, Oosten HR. Acute pancreatitis due to sulfamethoxazole-trimethoprim. South Med J. (1992) 85:10067. doi: 10.1097/00007611-199210000-00018

342. Bousfiha A, Jeddane L, Picard C, Al-Herz W, Ailal F, Chatila $\mathrm{T}$, et al. Human inborn errors of immunity: 2019 update of the IUIS phenotypical classification. J Clin Immunol. (2020) 40:66-81. doi: 10.1007/s10875-020-00758-x

343. Winkelstein JA, Marino MC, Johnston RB, Boyle J, Curnutte J, Gallin JI, et al. Chronic granulomatous disease: report on a national registry of 368 patients. Medicine. (2000) 79:155-69. doi: 10.1097/00005792-20000500000003

344. de Oliveira-Junior EB, Zurro NB, Prando C, Cabral-Marques O, Pereira PVS, Schimke LF, et al. Clinical and genotypic spectrum of chronic granulomatous disease in 71 Latin American patients: first report from the LASID registry. Pediatr Blood Cancer. (2015) 62:2101-7. doi: 10.1002/pbc. 25674

345. Marciano BE, Spalding C, Fitzgerald A, Mann D, Brown T, Osgood S, et al. Common severe infections in chronic granulomatous disease. Clin Infect Dis. (2015) 60:1176-83. doi: 10.1093/cid/ciu1154

346. Bassiri-Jahromi S, Doostkam A. Actinomyces and nocardia infections in chronic granulomatous disease. J Glob Infect Dis. (2011) 3:348-52. doi: 10.4103/0974-777X.91056

347. Agudelo-Flórez P, Prando-Andrade CC, López JA, Costa-Carvalho BT, Quezada A, Espinosa FJ, et al. Chronic granulomatous disease in Latin American patients: clinical spectrum and molecular genetics. Pediatr Blood Cancer. (2006) 46:243-52. doi: 10.1002/pbc.20455

348. Rieg S, Meier B, Fahnrich E, Huth A, Wagner D, Kern W V, et al. Differential activity of innate defense antimicrobial peptides against Nocardia species. BMC Microbiol. (2010) 10:61. doi: 10.1186/1471-2180-10-61

349. Mendez-Tovar LJ, Mondragon-Gonzalez R, Manzano-Gayosso P, LopezMartinez R, Hernandez-Hernandez F, Bonifaz A, et al. [Immunoglobulins in patients with Nocardia brasiliensis actinomycetoma]. Rev Argent Microbiol. (2004) 36:174-8.

350. Tillman BF, Pauff JM, Satyanarayana G, Talbott M, Warner JL. Systematic review of infectious events with the Bruton tyrosine kinase inhibitor ibrutinib in the treatment of hematologic malignancies. Eur J Haematol. (2018) 100:325-34. doi: 10.1111/ejh.13020

351. Lee WS, Boey CC, Goh AY. Pulmonary nocardiosis in a child with hyperimmunoglobulin E syndrome. Singapore Med J. (1999) 40:278-80.

352. Pintado V, Gómez-Mampaso E, Cobo J, Quereda C, Meseguer MA, Fortún J, et al. Nocardial infection in patients infected with the human immunodeficiency virus. Clin Microbiol Infect. (2003) 9:716-20. doi: 10.1046/j.1469-0691.2003.00588.x

353. Jayaschandran V, Gjorgova-Gjeorgjievski S, Siddique H. Pulmonary nocardiosis in a patient with idiopathic CD4 T-lymphocytopenia. Respir Case Rep. (2017) 6:e00283. doi: 10.1002/rcr2.283

354. Adjamian N, Kikam A, Wessell KR, Casselman J, Toller-Artis E, Olasokan $\mathrm{O}$, et al. Nocardia brain abscess and CD4(+) lymphocytopenia in a previously healthy individual. Case Rep. Immunol. (2015) 2015:374956. doi: 10.1155/2015/374956

355. Ercibengoa M, Càmara J, Tubau F, García-Somoza D, Galar A, MartínRabadán P, et al. A multicentre analysis of Nocardia pneumonia in Spain: 2010\&\#x2013;2016. Int J Infect Dis. (2020) 90:161-6. doi: $10.1016 / j . i j i d .2019 .10 .032$

356. Oh CS, Stratta RJ, Fox BC, Sollinger HW, Belzer FO, Maki DG. Increased infections associated with the use of OKT3 for treatment of steroidresistant rejection in renal transplantation. Transplantation. (1988) 45:68-73. doi: 10.1097/00007890-198801000-00016

357. Penkert H, Delbridge C, Wantia N, Wiestler B, Korn T. Fulminant central nervous system nocardiosis in a patient treated with alemtuzumab for relapsing-remitting multiple sclerosis. JAMA Neurol. (2016) 73:757-9. doi: 10.1001/jamaneurol.2016.0146

358. Sheikh-Taha M, Corman LC. Pulmonary Nocardia beijingensis infection associated with the use of alemtuzumab in a patient with multiple sclerosis. Mult Scler. (2017) 23:872-4. doi: 10.1177/1352458517694431

359. Mendez-Tovar LJ, Mondragon-Gonzalez R, Vega-Lopez F, Dockrell HM, Hay R, Lopez-Martinez R, et al. Cytokine production and lymphocyte proliferation in patients with Nocardia brasiliensis actinomycetoma. Mycopathologia. (2004) 158:407-14. doi: 10.1007/s11046-004-3126-4

360. Ali T, Chakraburtty A, Mahmood S, Bronze MS. Risk of nocardial infections with anti-tumor necrosis factor therapy. Am J Med Sci. (2013) 346:166-8. doi: 10.1097/MAJ.0b013e3182883708

361. Ford AC, Peyrin-Biroulet L. Opportunistic infections with anti-tumor necrosis factor- $\alpha$ therapy in inflammatory bowel disease: meta-analysis of randomized controlled trials. Am J Gastroenterol. (2013) 108:1268-76. doi: 10.1038/ajg.2013.138

362. Salmon-Ceron D, Tubach F, Lortholary O, Chosidow O, Bretagne S, Nicolas $\mathrm{N}$, et al. Drug-specific risk of non-tuberculosis opportunistic infections in patients receiving anti-TNF therapy reported to the 3-year prospective French RATIO registry. Ann Rheum Dis. (2011) 70:616-23. doi: 10.1136/ard.2010.137422

363. Wallis RS, Broder MS, Wong JY, Hanson ME, Beenhouwer DO. Granulomatous infectious diseases associated with tumor necrosis factor antagonists. Clin Infect Dis. (2004) 38:1261-5. doi: 10.1086/383317

364. Lee G, Robosa R, Fong G, Lee FJ, Lowe P, Pinto AN. Adult cervicofacial nocardiosis in the setting of IL-12/23 blockade. Australas J Dermatol. (2019) 60:323-4. doi: 10.1111/ajd.13046

365. Picard C, Fieschi C, Altare F, Al-Jumaah S, Al-Hajjar S, Feinberg J, et al. Inherited interleukin-12 deficiency: IL12B genotype and clinical phenotype of 13 patients from six kindreds. Am J Hum Genet. (2002) 70:336-48. doi: $10.1086 / 338625$

366. Luangwedchakarn V, Jirapongsaranuruk O, NiemeLa JE, Thepthai C, Chokephaibulkit K, Sukpanichnant S, et al. A novel mutation of the IL12RB1 gene in a child with nocardiosis, recurrent salmonellosis and neurofibromatosis type I: first case report from Thailand. Asian Pac J Allergy Immunol. (2009) 27:161-5.

367. Pedraza S, Lezana JL, Samarina A, Aldana R, Herrera MT, Boisson-Dupuis $\mathrm{S}$, et al. Clinical disease caused by Klebsiella in 2 unrelated patients with 
interleukin 12 receptor betal deficiency. Pediatrics. (2010) 126:e971-6. doi: 10.1542/peds.2009-2504

368. Prando C, Samarina A, Bustamante J, Boisson-Dupuis S, Cobat A, Picard C, et al. Inherited IL-12p40 deficiency: genetic, immunologic, and clinical features of 49 patients from 30 kindreds. Medicine. (2013) 92:109-22. doi: 10.1097/MD.0b013e31828a01f9

369. Eisenblätter M, Buchal A, Gayum H, Jasny E, Renner Viveros P, Ulrichs $\mathrm{T}$, et al. Nocardia farcinica activates human dendritic cells and induces secretion of interleukin-23 (IL-23) rather than IL-12p70. Infect Immun. (2012) 80:4195-202. doi: 10.1128/IAI.00741-12

370. Rosen LB, Pereira NR, Figueiredo C, Fiske LC, Ressner RA, Hong JC, et al. Nocardia-induced granulocyte macrophage colony-stimulating factor is neutralized by autoantibodies in disseminated/extrapulmonary nocardiosis. Clin Infect Dis. (2015) 60:1017-25. doi: 10.1093/cid/ciu968

371. Picard C, von Bernuth H, Ghandil P, Chrabieh M, Levy O, Arkwright PD, et al. Clinical features and outcome of patients with IRAK-4 and MyD88 deficiency. Medicine. (2010) 89:403-25. doi: 10.1097/MD.0b013e3181 fd8ec3

372. Corvilain E, Casanova J-L, Puel A. Inherited CARD9 deficiency: invasive disease caused by ascomycete fungi in previously healthy children and adults. J Clin Immunol. (2018) 38:656-93. doi: 10.1007/s10875-018-0539-2

Conflict of Interest: The author declares that the research was conducted in the absence of any commercial or financial relationships that could be construed as a potential conflict of interest.

Copyright $\odot 2020$ Martinez-Barricarte. This is an open-access article distributed under the terms of the Creative Commons Attribution License (CC BY). The use, distribution or reproduction in other forums is permitted, provided the original author(s) and the copyright owner(s) are credited and that the original publication in this journal is cited, in accordance with accepted academic practice. No use, distribution or reproduction is permitted which does not comply with these terms. 